\title{
Cizye Tahrirlerine Göre Antakya'da Gayrimüslim Cemaatler
}

\author{
Haydar Çoruh*
}

(ORCID ID: 0000-0002-7632-9721)

\section{Makale Gönderim Tarihi}

15.12.2019

\author{
Makale Kabul Tarihi
}

10.02.2020

\section{Özet}

Ulusçuluk ve milliyetçilik kavramlarının geliştiği Batı dünyasında devletler nüfus hareketlerine büyük önem verirken, Osmanlı Devleti bu potansiyeli daha ziyade vergiler ve askerlik mesleğini yapacak olan mükellefler açısından değerlendirmekteydi. Bu durum nüfus sayımlarını vergilendirilebilen hane reisi ve askerliğe elverişli erkeklerin sayılmasıyla sınırlandırmışır. Bu da imparatorluk çapında bir nüfus sayımı problemiyle karşı karşıya kalınmasına sebep olmuştur.

Antakya açısından meseleye bakıldığında durum pek de farklı değildir. Araştırmacılar çok çeşitli unsurlardan oluşan gayrimüslimler ile Müslüman ahalinin bir arada yaşadığı bu şehirde yaşayan nüfus kitlelerinin nasıl bir dönüşüme sahip olduğunu ortaya koymak gerektiğinde büyük problemlerle karşı karşıya kalmaktadırlar. Bu problemlerden kaynaklanan veri eksiklikleri vergi mükellefi erkek nüfustan ziyade çocuk ve kadın nüfusun hangi şartlarda azalıp çoğaldığını belirlemeye imkân vermemektedir.

Antakya ve çevresine ait 1694, 1842, 1843, 1844 ve 1846 tarihli ve en azından belirli bir döneme ait nüfus istatistikleri oluşturabilecek bir dizi tahrir bulunmaktadır. Bu tahrirler nüfus istatistiklerinin oluşturulmasında kullanılacak veri eksikliklerini az da olsa giderebilir niteliktedir. Bunlardan 1842 tarihli hariç diğerleri üzerinde herhangi bir çalışma yapılmamıştır. Bu defterlerden 1694 tarihli defterin dışında kalan 1842, 1843, 1844, 1846 tahrirleri hemen hemen aynı düzene sahip olmakla beraber, verilerden bazılarında zaman içerisinde değişkenlikler yaşandığı gözlemlenmektedir.

* Doç. Dr., Mustafa Kemal Üniversitesi, Fen Edebiyat Fakültesi, Tarih Bölümü, haydarcoruh@hotmail.com.

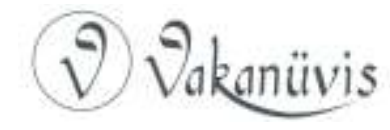


Bu makalede, yukarıda tarih sıralamasına göre verilen beş defterin karşılaştırmalı analizi yapılmıştır. Antakya, Süveydiye, Cebel-i Akra ve Kuseyr nahiyelerine ait vergi mükelleflerine ait nüfus, cizye ve mesleklerle ilgili değişkenlikler üzerinde durulmuştur.

Anahtar Kelimeler: Cizye, Gayrimüslim, Nüfus, Osmanlı, Tahrir.

\section{Non-Muslim Communities in Antakya According to Jizya Irritations}

\section{Abstract}

In the Western world, where the concepts of nationalism and nationalism developed, states attached great importance to population movements, while the Ottoman Empire evaluated this potential in terms of taxpayers who would do their duty and military service. This limited the censuses to the number of household heads who could be taxed and the number of men suitable for military service. This led to an empire-wide census problem.

From Antakya point of view, the situation is not very different. Researchers face big problems when it is necessary to reveal how the masses of the population living in this city, where the non-Muslims and the Muslim community live together. Data deficiencies resulting from these problems do not allow us to determine the conditions under which the child and female population declines and multiplies rather than the taxpayer male population.

There are a number of destructions of Antakya and its surroundings that can produce population statistics of at least a certain period, dated 1694, 1842, 1843,1844 and 1846. These destructions can overcome the shortcomings of the data to be used in the creation of population statistics. No studies have been carried out on any of these except 1842. Although the annotations of $1842,1843,1844,1846$, which are out of the book dated 1694, have almost the same order, some of the data have been observed to change over time.

In this article, comparative analysis of the five books given according to the date order was made. The variations related to the population, capacity and occupation of taxpayers of Antakya, Suveydiye, Cebel-i Akra and Kuseyr subdistricts were emphasized.

Keywords: Jizya, Non-Muslim, Population, Ottoman, Tahrir. 


\section{Giriş}

Günümüzde Hatay olarak bilinen Antakya ve çevresinden oluşan tarihsel bölge Akdeniz'in doğusundadır. Deniz ile kara arasında yaklaşık $22 \mathrm{~km}$ bulunmaktadır. Denizden yüksekliği 80 m olan şehir kuzeyde Nur Dağları ve güneyde Kel Dağ'ı arasında kalan ve Amik Ovası'nın da yer aldığı bir vadiyi kapsamaktadır ${ }^{1}$.

Antakya şehri, tarihin her devrinde önemli bir nüfusa sahip olmuştur. Bu nüfus genel olarak Akdeniz, Ortadoğu, Afrika ve Anadolu kıtalarından gelen göçler ile sürekli olarak beslenmiştir. Şehir Hıristiyanlığın ilk merkezi olan St. Pierre kilisesine sahip olması sebebiyle özellikle Avrupa kökenli hacıların bir durağı olmuş ve tarih boyunca güçlü Haçlı orduları tarafından istila edilmiş, zaman zaman bu istilalar sebebiyle nüfusunun büyük bir bölümünü kaybetmiştir.

Antakya, 1516 yılında Osmanlı Devleti'nin fethi sonrasında önce sancak statüsüyle Şam'a, ardından da kaza statüsüyle Halep Sancă̆ı'na dâhil edilmiştir. 1581 yılından itibaren kaza idaresi olarak teşkilatlandırılan Antakya Kuseyr, Altunözü, Cebel-i Akra, Süveydiye ve Şuğur nahiyeleriyle birleştirilmiştir². 1526 yılından itibaren Halep şehrinin bir parçası haline getirilmiştir ${ }^{3}$. XIX. yüzyılın ilk yarısına kadar aynı şekilde devam eden bu teşkilat, aynı tarihlerde Ordu nahiyesiyle birleştirilmiştir ${ }^{4}$. Yaklaşık 400 yıl Osmanlılar tarafından yönetilen bu şehir her türlü istila ve katliamlardan korunarak, nüfus bakımından da desteklenmiştir. Osmanlılar fethettikleri bölgelerde kurdukları nizam genellikle o beldede var olan ve i̇slâmiyet şartları içerisinde göze batmayan kanun ve nizamların muhafazası şeklindeydi. Yönetimin kalıcı

\footnotetext{
1 Yücel Dinç, Antakya (Hatay) Şehir Coğrafyası, (Yüksek Lisans Tezi, MKÜ, SEB), Hatay 2015, s. 1.

2 Enver Çakar, "16. Yüzyılda Antakya Vakıfları (1550 Tarihli Evkaf Defterine Göre)", Vakıflar Dergisi, Sayı: 43, Haziran 2015, s. 10; Ahmet Gündüz, XVI. Yüzyılda Antakya Kazası (1550-1584), Antakya 2009, s. 48 vd; Abdülkadir Gül, "XVI. Yüzyılda Antakya Kazası'nın Demografik Yapısı", Turkish Studies, c. 4/3, Bahar 2009, s. 1027.

${ }^{3}$ Çakar, a.g.m., s. 10; Gül, a.g.m., s. 1028.

${ }^{4}$ Merkez Kazası Antakya, Süveydiye Nahiyesi, Cebel-i Akra, Kuseyr Nahiyesi, Altınözü Nahiyesi, Ordu Nahiyesi ve bunlara bağıı köy ve mezralardan oluşmaktadır (Jülide Akyüz, " 19. Yüzyılda Antakya-İskenderun Bölgesinde Nüfus Hareketliliği”, Fırat Üniversitesi Sosyal Bilimler Dergisi, c. 18, Sayı: 2, s. 380; Adem Kara, 19. Yüzyılda Bir Osmanlı Şehri Antakya, IQ Yayınları., İstanbul, 2005, s. 23).
}

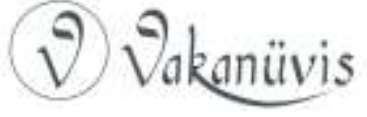


olmasını sağlamak amacıyla da fetih bölgelerinde ekonomik refahı sağlamak amacıyla da genelde vergi muafiyetine gidilirdi. Oysaki bölgeden çıkarılmış olan istilacılar bu düzenin tam tersini, işgal edilen beldenin bir daha başlarını kaldıramamalarını sağlamak amacıyla öncelikle sömürülmesine ve sonrasında bağımlı kılınmasına özen gösterilirdi ${ }^{5}$.

Osmanlı Devleti'nin, yabancı istilacılara karşı kullandığı bu silah zaman içerisinde unutulmuş, kaybedilen ticaret yollarıyla zayıflayan imparatorluk fakirleşince ağır vergiler toplumu yavaş yavaş hamilerinden uzaklaştırmaya başlamıştır. Yüzyıllar içerisinde kurulmuş olan refah kardeşliği, istilacı zihniyetlerin dinsel söylemlerle ekmeye başladıkları ayrılığa yönelik nifak tohumları, Papa'nın ve Fransa'nın desteğindeki misyonerler tarafından beslenmiştir. Misyonerlerin dinsel söylemler açısından benzerlikler taşıyan Antakya'nın Hıristiyanlarını XVIII. yüzyılın sonlarına doğru Osmanlıya tamamen yabancılaştırmıştır. Nihayetinde Antakya'da kurulmuş olan Müslim ve gayrimüslim refah toplumu hızlı bir şekilde yerini kaosa, dini ve ırki ayrışmalara bırakmıştır. $\mathrm{Bu}$ da Antakya Hıristiyanlarını ya Misyonerlere biat ettirmiş veya saldırılar karşısında çaresiz kalanları kendilerini daha güvende hissedecekleri bölgelere göç etmesine ve yüzyıllardır varlığını devam ettiren kültür unsurlarının şehri terk etmesine sebep olmuştur ${ }^{6}$. Buna rağmen şehir üç semavi dinin merkezi olma özelliğini her dönemde korumuştur. Yahudilikle başlayan ve paganizmi silip süpüren Hıristiyanlık yerini büyük oranda Müslümanlığa terk ettiği 630'lu yıllarda Araplar gibi, 1516'daki fetih sonrasında Osmanlılar da her iki dinin şehirdeki varlığını ve izlerini en yüksek düzeyde korumayı vazife edinmişlerdir.

1694 ve $1842-1846$ yılları arasında vücuda getirilmiş bir dizi tahrir defterinden elde edilen verileri kullanarak oluşturulan bu makalede bazı özel hususlara dikkat çekmek amacıyla, "Tahrir Defterleri”nde kullanılan bazı terimler mümkün mertebe orijinal şekliyle verilmeye çalışılmıştır. Şahıs ve yer adları, ölçü birimleri, cizye ile ilgili terimler ve topluluk ifadeleri gibi önem arz eden hususlar mümkün mertebe her tahrirde

\footnotetext{
${ }^{5}$ Gertrude Bell, Review of The Civil Administration Mesopotamia, Dublin 1920, s. 74 vd.

6 Haydar Çoruh, Arap ve Rum Matranların iktidar Mücadelesi Sürecinde Antakya Ortodoks Kilisesi, Kriter Yayınları, İstanbul 2019, s. 1-19.
}

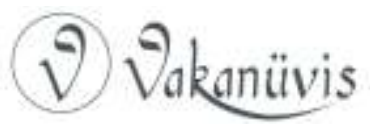


aynı şekilde kullanılmaları ve araştırmacıların benzerliklerden faydalanarak terimler hakkında bir fikir edinebilmelerini sağlamak amacıyla bu ifadeler tırnak içinde (" ") verilmiş ve sadeleştirmeye gidilmemiştir.

\section{Cizye Tahrirlerinin Nüfusun Tespitinde Veri Olarak Kullanımı}

Nüfus defterleri ve cizye evrakı gibi malzemeler demografi çalışmalarında birbirini tamamlayan unsurları oluşturur. İmparatorluk düzeyine erişmiş olan devletlerde birbirinden farklı topluluklar arasında dinsel, ırksal ve mezhepsel ayrımlar bir arada yaşamanın formülü olmuştur. XIX. Yüzyıl öncesinde toplumlar arasındaki en belirgin farklılığı din oluştururken, yüzyılın başlarında gerçekleşen Fransız ìtilâli'nin toplumlara aşıladığı milliyetçi söylemler, din faktörünün yerini giderek ırki temellere dayanan milliyet kavramının almasına sebep olmuştur.

Bir İslâm devleti olan Osmanlı Devleti'nde de din XIX. yüzyıla kadar tebaanın en belirgin ve ayırt edici göstergesi olmuştur. Selefleri gibi aynı geleneğe bağlı olması sebebiyle vergi toplama işleri İslâm dininin geliştirdiği zimmi hukuka dayandırılmıştır. Bu sistem zamanla "Millet Sistemi" denilen yeni bir kavramı ortaya çıkarmıştır7. Gayrimüslim tebaaya ait verilerle ilgili kaynakların/nüfus vs. defterlerin yetersiz olduğu durumlarda araştırmacılar zimmi hukuk çerçevesinde gayrimüslimlerden alınan vergilere ait verileri içeren ve adına cizye evrakı denilen belgeleri kullanılmışlardır.

Bu bakımdan cizye evrakının nasıl ve ne zaman nüfus verileri haline gelmiş olduğunu izah ede bilmek için bu belgeleri ortaya çıkaran tahrirler hakkında biraz bilgi verilmesi Osmanlı Devleti'nin sahip olduğu demografik yani nüfus bilimi anlayışının daha iyi kavranmasına yardımcı olacaktır.

Zimmi hukukunun bir parçası olan gayrimüslim cemaat yılda bir defa alınan ve adına cizye denilen bir vergiyi ödemek zorundaydı. Osmanlı Devleti, ilk İslâm toplumlarında uygulanan bu sistemi biraz daha yumuşatmak suretiyle farklılaştırmış, hatta kişiye, aileye veya gruplara

\footnotetext{
7 Bkz. Cevdet Küçük, "Osmanlı Devleti'nde "Millet Sistemi”, Osmanlı Ansiklopedisi, c. IV, (Edit: Güler Eren), Yeni Türkiye Yayınları, Ankara, 1999, s. 208- 216; Cevdet Küçük, "Osmanlılarda "Millet Sistemi" ve Tanzimat", Tanzimat'tan Cumhuriyet'e Türkiye Ansiklopedisi, c.4, İletişim Yayınları, İstanbul, 1985, s.1007- 1024.
}

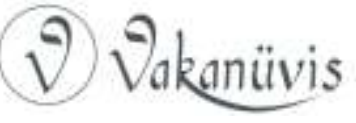


göre yeni modeller oluşturarak ödenmesinde kolaylıklar sağlamıştır. Cizye, Osmanlı hukuk sistemi içerisinde bir taraftan dini bir mesele olmaya devam etmiş, diğer taraftan da önemli bir gelir kaynağı olması hasebiyle maliye kalemleri tarafından sıkı takip edilmiştir ${ }^{8}$.

Cizye vergisi, İslâm hukuku çerçevesinde ele aldığından toplanma şekline büyük bir kıymet atfedilmekteydi. Bu kıymetin bir diğer veçhesi ise verginin hazine kalemleri arasında giderek artan bir oranda vazgeçilmez bir gelir kaynağı haline gelmesiydi. Fiskal bir anlayışla yani karlılık oranının mümkün mertebe belirli bir düzeyin altına indirmemeye özen gösteren Osmanlı maliyesi, cizye vergisinin hazine için kazandığı bu önem sebebiyle gayrimüslim vatandaşların Müslüman olmaya özendirilmesini tavsiye etmemiştir?

Osmanlı Devleti, hazinenin ihtiyaç duyduğu gelirin bir kısmını oluşturan cizye miktarlarında piyasa şartlarını dikkate alarak zaman zaman değişikliğe gitmiştir. Bu değişikliklerin en önemlisi 1691 yılında yapılan iyileştirmedir ${ }^{10}$. Bu iyileştirme sayesinde uzun yıllardır hiçbir değişime uğramayan cizye tahsili 1691'de ilk defa yeni bir düzenlemeye tabi tutulmuş ve vergiye tabi olan ve olmayanların ayrımına gidilmiştir.

\footnotetext{
8 İsmail Özcoşar-Hüseyin Haşimi Güneş, “Osmanlı Devleti'nde Cizye Ve 19. Yüzyıla Ait Bir Cizye Defteri: Cizre Sancağı'nın Cizye Defteri (Cizye Defter Numarası:375)", Elektronik Sosyal Bilimler Dergisi, C. 5, S. 15, 2006, s. 160.

9 Özcoşar-Güneş, a.g.m., s. 160. Emevi döneminde cizye vergisinin hazine için önemi hakkında bkz. Ali Köse, "ihtidâ", DiA, c. 21, s. 556. Cizye vergisi gayrimüslimlerin her birinden alınmakla beraber bu tahsilatın belirli şartları vardı. Buna göre verginin tahsil edileceği kişinin akil baliğ olmasına, sağlam olmasına ve iş ve güç sahibi olmasına, en azından 300 akçe tutarında bir gelirinin olmasına dikkat edilirdi. Kadınlardan, çocuklardan, amelmande olanlardan ve mal ve mülk sahibi olmayan müderrislerden alınmazdı. Bir görev karşılığı vergi muafiyeti olan zümrelerden de cizye alınmadığı bilinmektedir. Bunlar arasında voynuklar ve martalosların yanı sıra Eflak ve Buğdan gibi zümreler de bulunmaktaydı (Özcoşar-Güneş, a.g.m., s. 161). Ayrıca ihtidâ hakkında bkz. Cengiz Kartın, "Türk - Ermeni illişkilerindeki Hoşgörü İklimi Çerçevesinde ihtida Hareketleri", Hoşgörü Toplumunda Ermeniler (I. Uluslararası Ermeni Sempozyumu), Kayseri, 1-4 September 2007, c. 1, ss. 521-534.

${ }^{10}$ Bu iyileştirmeye göre yapılan yeni düzenleme hakkında bkz. Halil İnalcık, "Cizye", DiA, c. VIII, İstanbul 1993, s. 47. Cizyenin tahsili ve uygulamada yeni değişiklikler hakkında bkz. Burak Kocaoğlu, "Osmanlı'da Cizye Vergisi ve İtfaiye Çalışmaları", Iğdır Üniversitesi Sosyal Bilimler Dergisi, Sayı: 10, Ekim 2016, s. 158.
}

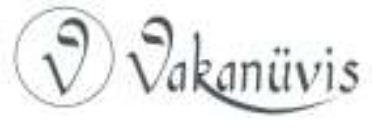


$\mathrm{Bu}$ yoklama sonrasında cizye mükelleflerinin ellerine verilen belgeler sayesinde vergi toplama usulü kontrol altına alınmışır ${ }^{11}$.

Osmanlı Devleti, sosyal bir devlet anlayışının bir gereği olarak, Müslüman ve gayrimüslim tebaayı birbirinden farklı addetmiş ve yapılan nüfus tahrirlerinde her iki toplumu ayrı ayrı defterlere kaydetmişti. Bu kayıtlar tutulurken önce nüfus yazılmış daha sonra da bu nüfusa vergi tahrir edilmiştir. Bu kayıt sisteminde Müslümanların vergileri ile gayrimüslimlerin vergileri ayrı ayrı cetvellerde gösterilmiştir. Bu sebeple XIX. Yüzyılda başlatılan modern nüfus sayımlarına kadar Müslim ve gayrimüslim tebaanın vergileri için ayrı evraklar oluşturulmuştur. Bu sistem avarız, nüzul, cizye ve esame gibi birbirinden farklı evrakların ortaya çıkışını hazırlamıştır. XIX. Yüzyılda modern nüfus sayımlarına yönelik evraklar hazırlanırken Müslim ve gayrimüslim tebaanın vergileri Temettü defterleri örneğinde olduğu gibi hane bölümünde gösterilirken, cizye söz konusu olduğunda gayrimüslimler için kişiye özel ayrı evrak düzenlenmeye devam edilmiştir. Düzenlenen bu evrak gayrimüslimlere ait bu verginin cinsini ve miktarını gösteren evrak olarak literatüre girmiştir. Yukarıda da belirtildiği üzere nüfus verilerinin yeterli olmadığı dönemler için veya nüfus verilerine yönelik karşılaştırmalar yapabilmek için kullanılan bu evrak, XIX. Yüzyılın ikinci çeyreğinden itibaren 1842, 1843, 1844, 1846 Antakya'ya ait defterlerde olduğu gibi nüfus defterleriyle birleştirilmiştir.

Modern manada yapılmış nüfus sayımları dışında, sadece cizye miktarlarının kaydedildiği defterlere çok az rastlanmaktadır. Bu tür defterlerde mükelleflerin yer aldığı sütünün üst tarafında hane numarası, vergi-i mahsusa, öşür bedeli ve cizye bedeli gibi verilere yer verilmiştir ${ }^{12}$.

11 İnalcık, a.g.mad., s. 46. Cizye ilk dönemlerde hane başına alınan bir vergiyken, 1691 reformu sonrasında hane sistemi terk edilerek belirli bir yaşa gelen tüm yetişkin erkek nüfustan tahsil edilmeye başlandı. Bu itibarla vergi mükelleflerine kâğıt veya varak denilen bir belge verilmek suretiyle bu belgenin yoklamaları yapılmaya devam edilmiştir (Güven Dinç, "Tanzimat Dönemi Cizye Defterlerine Göre Antalya Gayrimüslimleri", Mediterranean Journal of Humanities, c. VII/2, Antalya 2017, s. 161.

12 Zülfiye Koçak, “H. 1102 (M. 1690-1691) Tarihli Diyarbekir Eyaleti Cizye Defterinin Tanıtımı Ve Tahlili”, Tarih Araştırmaları Dergisi, c. 37, Sayı: 63, 2018, s. 221, dipnot: 6-7.

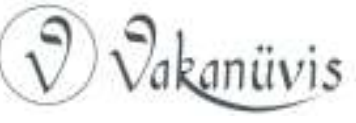




\section{Nüfus Tahrirleri}

Cizye vergisi hakkında verilen bu kısa bilgiye ilave olarak nüfus tahrirleri hakkında da bazı bilgilerin hatırlatılmasında fayda vardır. Nüfus ve demografi çalışmalarında, klasik Osmanlı dönemine ait veriler büyük oranda Tapu Tahrir Defterleri'nden derlemiştir ${ }^{13}$.

XVII. yüzyılın başlarından itibaren yeni fetihlerin yapılamaması, tapu tahrirlerinin sona ermesine ve sonraki dönemlerde tahrirlerin genellikle eski yani atik defterler üzerinden yapılmasına sebep olmuştur. Bu da Osmanlı Devleti'nde meydana gelen büyük demografik değişimlere rağmen nüfus verilerinin sürdürülebilir bir şekilde denetim altına alınmasını engellemiştir ${ }^{14}$.

XVIII. yüzyılın başlarından itibaren Avrupa'da yaşanan gelişmeler ve yeni icat bilimsel yöntemler, nüfus biliminde modern usullerin kullanılmasını sağlamıştır. İmparatorluklardan milli devletlere geçiş sürecinde her devlet kendi öz topraklarında kendi kimliğini oluşturabilmek amacıyla nüfus verilerini saptamak ve en doğru biçimde kaydedebilmek için kadın, erkek, çocuk ve yaşlı ayrımına gitmeksizin nüfuslarını bireyi esas alarak tespit ve kaydetmeye başlamışlardır. Bu sayede toplumda aksayan yönleri teşhis ve tedavi etme imkânına sahip oldukları gibi, bireyin ihtiyacı olan eğitim, sağlık ve diğer sosyal imkânları daha hızlı bir şekilde hazırlamaya muvaffak olmuşlardır. Bu yeni sistemle köyden şehre göçü kontrol altına alarak, şehirlerde aşırı nüfus

13 Tapu Tahrir defterleri hakkında kısa bir açıklama için Bkz. Zeki Arıkan, "Tapu-Tahrir Defterleri Yayınıyla İlgili Bir Tasarı", Osmanlı Araştırmaları, c. XIII, İstanbul 1993, s. 6974. Ayrıca şu kaynaklara da bakılabilir: Hüdavendigâr Livası Tahrir Defterleri (haz. Ömer Lutfi Barkan - Enver Meriçli), Ankara 1988, s. 1-144; Feridun M. Emecen, "Sosyal Tarih Kaynağı Olarak Tahrir Defterleri", Tarih ve Sosyoloji Semineri, 28-29 Mayıs 1990: Bildiriler, İstanbul 1991, s. 149-155; Erhan Afyoncu, "Türkiye'de Tahrir Defterlerine Dayalı Olarak Hazırlanmış Çalışmalar Hakkında Bazı Görüşler", Türkiye Araştırmaları Literatür Dergisi, I/1, İstanbul 2003, s. 267-286; Mehmet Öz, "Tahrir Defterlerinin Osmanlı Tarihi Araştırmalarında Kullanılması Hakkında Bazı Düşünceler", Vakıflar Dergisi, Sayı: 22 (1991), s. 429-439.

14 Özcan Tatar, “Elazığ Tapu Müdürlüğü’ndeki Tapu Kayıt Defterlerinin Harput Tarihi Açısından Önemi", Fırat Üniversitesi Harput Uygulama ve Araştırma Merkezi Geçmişten Geleceğe Harput Sempozyumu, Elazığ 23-25 Mayıs 2013, Elazığ 2013, s. 587-588.

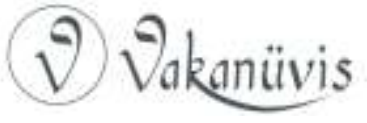


yığılmalarını engelledikleri gibi, köylerdeki yaşamı daha yaşanııır kılacak çözümler de üretebilmişlerdir ${ }^{15}$.

Osmanlı Devleti ise yüzyılın başlarından itibaren Avrupa ile kurduğu yeni ilişkiler çerçevesinde Lale Devri'ni yaşarken bu yeni politikanın pek farkında olamamış, hatta ülke nüfusunu ortaya koymak yerine vergi ve asker meselesini dert edinerek, topraklarındaki insan kaynaklarının nasıl şekillendiği konusunda herhangi bir çaba gösterememiştir. Bu da ülke yönetiminde ortaya çıkan boşlukların organize edilmesini sağlayacak olan nüfus biliminin gelişmesini ve sağlıklı verilerin oluşturulmasını engellemiştir. Bununla beraber yüzyılın sonuna doğru Avrupa'daki bu yeni düzen, imparatorlukları parçalanmanın ve dağılmanın eşiğine getirince Osmanlı devlet yöneticileri ülke kaynaklarını dış güçlerden korumak ve daha verimli hale getirebilmek için bir takım tedbirler almak istemişlerdi. Bu tedbirlerin başında askeri sistemi güçlendirmek ve bu sistemi besleyen kaynakları daha verimli kılabilmek için bir dizi ıslah faaliyeti başlatmak olmuştur. Bu ıslah yapılırken insan faktörü öne çıkarılmakla beraber, insan kitleleri öncelikle hazine ve orduyu besleyecek şekilde yeni bir değerlendirmeye tabi tutulmuştur ${ }^{16}$.

15 Ibrahim Serbestoğlu 19. Yüzyılda özellikle Avrupa'da gelişen nüfus ve toplum ilişkisini şu ifadelerle ortaya koymaktadır "... Sanayileşme, kapitalizm ve kentleşme süreçleriyle birlikte insanlar fabrikalara ve kentlere akın etmiştir. Kentin yeni sakinleri bir arada yaşamak için kurallar oluşturmak ve gelenekler yaratmak zorundaydılar. Bu gelenek modern anlamda "toplum" denilen birlikteliği ortaya çıkartmıştır. Doğal olarak toplumun davranış ve ilkelerini inceleyen sosyoloji bilimi de bu dönemin ve sürecin ürünüdür. Tüm bu nüfus hareketleri ve değişimlerinin sonucu olarak 18. yüzyılın ikinci yarısından itibaren devletlerin nüfuslarını tam olarak tespit etmek amacıyla harekete geçtikleri görülmektedir. 19. yüzyılın ortalarından itibaren ise nüfus hakkında çalışmalar artmıştır. Yani 19. yüzyıl "demografi çağı"dır. Devletler nüfuslarını tam olarak tespit etmenin çabası içindedirler...." (i. Serbestoğlu, "19. Yüzyılda Osmanlı Devleti'nde Nüfus Algısının Değişimi Ve Nüfusu Arttırma Çabasında Müfettişlerin Rolü", Balikesir University The Journal of Social Sciences Institute, Volume: 17, Number: 31, June 2014, s. 259-261) ifadesini kullanarak Avrupa'da nüfus ile ilgili değişen fikri gelişmeye dikkat çekmiştir.

16 Nüfus sayımı meselesi Sultan II. Mahmud'a arzedildiğinde padişahın fikri acil olarak kurmak istediği ordunun kaynaklarını oluşturmaya yönelik olmuştur. Bu hususta “....Izmit kadısı Hüsameddin'in tavsiyesi üzerine Sadaret Kaimakamı, padişaha sayımda nüfusun yaşa göre sınıflandırılarak kaydedilmesini teklif etmişti. Teklife göre sekiz yaşın altındaki erkekler asgar (en küçük), sekiz-on beş yaş arasındakiler sagir (küçük), on beş ile kırk yaş arasındakiler şabb-i emred (sakalsız), kırk- altmış yaş arasındakiler sinn-i vusta (orta yaş) ve altmış yaş üstündekiler pir (yaşlı) olarak sınıflandırılıyordu. Yeni bir

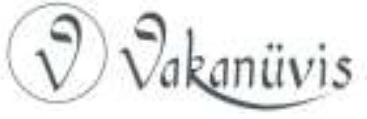


Her ıslahat döneminde öncelik yoklamalara ve sayımlara verilerek, ordu ve hazineyi destekleyecek iyi bir vergi sistemi kurulmaya çalışılmıştır. Bunun için de bütün imparatorluk çapında genel nüfus ve emlak sayımları yapılması için klasik dönemden biraz daha farklı bir tahrir geleneği kurgulanmıştır. Buna göre nüfus sayımları kişisel verilerin tamamını içerecek şekilde yeniden düzenlenmiştir. Bu düzenlemede nüfus, vergi, emlak ve ticari kazançlar ayrı cetvellerde gösterilmiştir. Vergi mükellefiyetinin yanı sıra eskisinden farklı olarak bir hanede bulunan erkek, çocuk ve yaşlı ayırt edilmeksizin bütün aile fertleri tahrire tabi tutulmuştur. Bu tavır değişikliği çağdaş Avrupa ülkelerinden yaklaşık yarım asır sonra Osmanlı Devleti'nde modern nüfus sayımlarının yapılmasını sağlamıştır. Ancak bu nüfus sayımlarının, Batı ile uyum sağlamaya yönelik atılan adımların yoğunlaştığı 1830'lu yıllara rastlaması dikkat çekicidir ${ }^{17}$. Bu husus dönemin önemli mütefekkirlerinden biri olan Vakanüvis Ahmet Lütfi Efendi tarafından dahi tam olarak idrak edilememiştir. Ahmet Lütfi Efendi sayımı, imparatorluğun erkek nüfusunun tespiti ve mali kaynakların yeniden belirlenmesi amacıyla yapıldığı şeklinde yorumlamıştır ${ }^{18}$.

Osmanlı Devleti'nin değişen dünya düzenine ayak uydurması için bir taraftan sultanlar, diğer taraftan bürokrasi büyük çaba harcamaktaydı. Ancak bu iki kurumu maksatta aynı düşünceleri paylaşıyor olsalar da nüfus sayımlarının uygulamalarıyla ilgi farklı düşünceleri olduğu anlaşılmaktadır. Meseleye daha modern bir açıdan bakan İznik

düzenleme teklifine karşılık Sultan II. Mahmud, sayımın dikkat ve itina gerektiren bir konu olduğuna vurgu yaparak, eski usulle yapılması talimatını vermişti. Yani nüfusu yaş gruplarına ayırmaksızın askerlik hizmetine uygun olanlarla vergi mükelleflerinin belirlenmesine yönelik sayım yapılmasını yeterli görmüştü." (Serbestoğlu, a.g.m., s. 260).

${ }^{17}$ Enver Z. Karal, Osmanlı Imparatorluğu'nda ilk Nüfus Sayımı (1831), Ankara 1943, s.12. 1831 nüfus sayımı aslında 1826 Yeniçeriliğin kaldırılması sebebiyle askerlik yapabilecek nüfusu ortaya çıkarmak amacıyla başlatılmıştı. Ancak 1828-1829 Osmanlı Rus savaşı nedeniyle askıya alınmış, 1830-1831 yılları arasında icra edilmişti. Sayım sırasında Müslim ve gayrimüslimler için ayrı defterler tutulmuştur. Şahısların yerli ve yabancılık durumları da defterlerde ayrı sütunlarda gösterilmiştir (Mehmet Güneş, "Osmanlı Dönemi Nüfus Sayımları ve Bu Sayımları İçeren Kayıtların Tahlili", Akademik Bakış, c. 8, Sayı: 15, Kış 2014, s. 226; Muhammed Sarı, Muttalip Şimşek, "1841 Tarihli Nüfus Defterine Göre Söke'de Rumların Nüfus Yapısı”, Uluslararası Sosyal Araştırmalar Dergisi, c. 9, Sayı: 44, Haziran 2016, s. 485).

${ }^{18}$ Ahmet Lütfi Efendi, Tarih-i Lütfi, c. III, Dersaadet 1292, s.143-144.

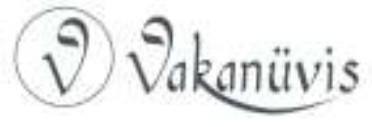


Kaymakamı Hüsamettin'in karşısında daha gelenekçi olan Sultan II. Mahmud'un direnişinin kırılamamış olması sayımların modernleştirilmesini engellediği gibi, vergilendirmenin de eski usullere göre yapılmasıyla ilgili yeni bir düzenlemeye de gidilmesi mümkün olmamıştır. Sultan II. Mahmud meseleye adaleti teminde zengin ile fakirin farklı imkânları olduğu gerçeğinden hareket ederek, vergilendirilmelerinin de farklı bir şekilde yapılması gereği üzerinde dururken ve hatta direnirken, bürokrasi vergilendirmenin tek düze olmasının hazine için daha faydalı ve daha kazançlı olacağı üzerinde duruyordu. Ancak bu iki görüş zamanın koşullarında Sultan II. Mahmud'un konumu sebebiyle birbirinin alternatifi olamayınca, hem nüfus sayımı ve hem de vergi meselesi çok az nispette modern, buna karşıık çok fazla gelenekçi ve eski usule uygun olarak yapılmıştır. Hatta İnik Kaymakamı oluşturduğu cetveli Sultan'a sunmakla beraber, tezkeresine yazdığı şu husus, o tarihte modern usullerin Osmanlı maliyesinde pek de anlaşılmadı̆̆ını ortaya koyması açısından manidar olsa gerek. Cetveli kastederek "kimse bundan bir şey anlamayacaktır." Kaymakam Paşa'nın bu tavrı dahi uygulamayı düşündüğü metodun ve modern bir tarzda yapılması için uğraştığı sayım şeklinin, padişahın onayını alamamasından sıkıntı duyduğunu ortaya koymak için yeterli olsa gerek. Hatta Sultan II. Mahmud'un sayım konusunda yeni fikir ve tecrübelerle zaman kaybetmeyi değil, aksine var olan bir sistemle en kısa zamanda intiyaç duyduğu insan kitlelerinin ve mali imkânların ortaya çıkarılmasını istediği, "hiçbir memurun usul-i sabıkadan ayrılmaması" yönündeki tembihatından anlaşılmaktadır ${ }^{19}$.

Sultanın direnişine ve sahadaki uygulamaları eski şekliyle sürdürmeye çalışmasına rağmen 1831 Modern Nüfus Sayımı, imparatorluk sisteminde bir zihniyet değişimi getirdiği yadsınamaz. Devlet o zamana kadar öncelikle vergi mükelleflerini sistemin bir parçası olarak kabul ederken, geri kalan fertleri ise bu mükelleflerin vesayetine dâhil etmekteydi. 1831 nüfus sayımından başlatılarak yapılan diğer bütün sayımlarda devlet toplumun bütün fertlerini tek tek ve gelirlerine göre (temettü) vergilendirme yoluna gitmiştir. Bu durum kişi hak ve hürriyetlerinin önemine vurgu yapılmasına ve bundan asla taviz

${ }^{19}$ Kemal Karpat, Osmanlı Nüfusu (1830-1914) Demografik ve Sosyal Özellikleri, Tarih Vakfı Yurt Yayınları, İstanbul 2003, s. 56 vd.

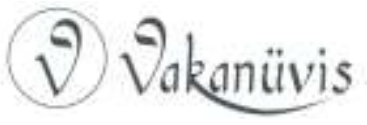


verilemeyeceğine dair ilk düzenlemelere zemin hazırlamıştır. Tanzimat Fermanı bu değişimin yazılı bir belgesi olarak ortaya çıkmış olup klasik döneme ait toplumcu anlayıştan yavaş yavaş bireyi ön plana alan yeni bir anlayışa geçişin belgesi olmuştur. Öyle ki 1829 'da başlayan bu değişim süreci 1853 yılına kadar aynı düzende devam etti. Kazalar nüfus sayımının köşe taşı olarak nitelendirilmişti. Bu sebeple kazalarda nüfus memurları bütün doğum, ölüm ve göç meselelerini yıl için de birkaç defa merkeze bildirmekte ve nüfus verileri bu bildirimlere göre yenilenmekteydi ${ }^{20}$.

Nüfus verileri konusunda oldukça fazla yol kat etmiş olan Osmanlı yöneticileri bu yeni döneme gelinceye kadar ekonomik ve sosyal kaynakları oluşturmayı başarmışlardı. Modern nüfus sayımına paralel olarak yapılan emlak tahrirleri ve cizye tahrirleri devletin ihtiyaç duyduğu insan kaynaklarının nereden ve ne şekilde temin edileceği hususunda lazım olan verilerin toplanmasını sağladığı gibi, bu veriler kullanılarak vergilerin verimliliği artırılmaya çalışılmışı ${ }^{21}$.

Resmi açıklamalara bakıldığında sayımın, mal değerlerindeki değişimi, toprakların el değiştirmesinden kaynaklanan yeni gelir kalemlerini, derbent gibi muafiyetlerin ortadan kalkmasıyla yolların ve köprülerin bakımı karşılığında vergilendirilmeyen kişi ve grupların eşit vergi sistemiyle yeniden yapılandırılması, askeri hizmete uygun

\footnotetext{
${ }^{20}$ Karpat, a.g.e., s. 58.

${ }^{21}$ Adem Kara, "XIX. Yüzyılın İlk Yarısında Antakya'da Yerleşme Ve Nüfus", Ankara Üniversitesi Osmanlı Tarihi Araştırma ve Uygulama Merkezi Dergisi (OTAM), Sayı: 17, Ankara 2005, s. 6-7. Adnan Çimen, Osmanlı Devleti'nin 1831 sayımının en önemli sebebi olarak Yeniçeri Ocağı'nın kaldırılması sonrasında kurulan yeni ordunun asker ihtiyacını karşılayacak tespitleri yapmak ve vergi tahsilinde var olan aksaklıkları düzeltmek ve cizyenin yeniden tayinini sağlamak şeklinde ifade eder (Adnan Çimen, "Sayım, Kayıt Düzeni Ve Teşkilatlanma Açısından Osmanlıda Nüfus Hizmetleri", Gazi Üniversitesi iktisadi ve Idari Bilimler Fakültesi Dergisi, Sayı: 14/3, Ankara 2012, s. 194). Mahir Aydın 1831 nüfus sayımının Müslim ve gayrimüslim nüfusu ortaya çıkarmayı, II. Mahmud döneminde Yeniçeri Ocağı'nın kaldırılıp yeni bir ordu kurulması ve askere alınabilecek Müslim erkek nüfusu ile ülkedeki nüfus değişkenlikleri sebebiyle cizyede meydana gelen değişim görmek amacıyla yapıldığını ifade eder (Mahir Aydın, "Sultan II. Mahmud Döneminde Yapılan Nüfus Tahrirleri", Sultan II. Mahmud ve Reform Semineri, 28-30 Haziran 1989, İstanbul 1990, s. 83; İsmail Kıvrım, "Nüfus Ceride Defterlerine Göre 19. Yüzyılın Ortalarında Giresun'un Nüfus Yapısı", Karadeniz Incelemeleri Dergisi, Cilt 10, Sayı 10, 2011, s. 54).
}

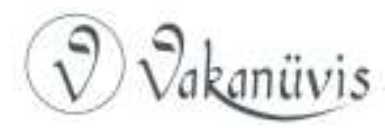


Müslüman sınıfların tespiti, yeni teşkil edilecek askeri sınıfların ve ordunun teçhizini sağlayacak cizye gelirlerinin eksiklerinin giderilerek yeniden fiyatlandırılmasıyla ortaya çıkacak yeni gelir kalemlerinin temini gibi özel beklentilerle yapıldığı anlaşılmaktadır ${ }^{22}$.

Ancak bu konuda atılan adımlar bazen beklentilerin tam tersi sonuçlar doğurabilmiştir. Bu yeni döneme rağmen eski zihniyetten kurtulma imkânının olmadığı kısa bir süre sonra anlaşılmıştır. Gelenekçi zihniyet ile modern zihniyetin sahada bir çatışma ortamı hazırlaması, fermanın taşrada anlaşımasını engellemiştir. Bunda fermanın yeni vergiler getireceği endişesi etkili olmuştur. Bu endişeler imparatorluğun önemli kentlerinde isyanların çıkmasına sebep olmuştur. Erzurum, Van ve Trabzon bölgelerinde Tanzimat uygulamalarına karşı bölgesel isyanlar çıkmıştır. Bu isyanlar söz konusu bölgelerde yeni muhtar yönetimlerin doğmasına sebep olmuştur. Bu yeni zümrelerden her biri el altında bulundurdukları güçler sayesinde devlet içinde devlet gibi hareket ederek, sahip oldukları insan kaynaklarını arzu ettikleri siyasi mücadelelerin birer parçası haline getirebilmişlerdir ${ }^{23}$. Osmanlı Devleti kısa bir süre içerisinde bu isyanları bastırarak gerekli önlemleri almış ve asayişi temin edebilmiştir. Yaklaşık beş yıllık bir zaman zarfında ülkenin hemen her bölgesinde Tanzimat yasaları uygulanabilir hale getirilmiştir. Osmanlı Devleti Tanzimat yasalarının uygulanmasını ve yerleşmesini temin edebilmek ve ordunun ıslahını ve toparlanmasını sağlayacak masrafları karşılamak üzere ayrı bir hazine oluşturmaya karar vermiştir. $\mathrm{Bu}$ kararı uygulayabilmek için de hazineye aktarılacak gelirlerin kaynağını teşkil edecek nüfus ve vergi tahrirlerinin yapılması için bir takım önlemler alınmıştır.

\footnotetext{
22 Karpat, a.g.e., s. 58.

${ }^{23}$ Klasik dönem vergi sisteminin ortaya çıkardığı çıkar gruplarının Tanzimat sonrasında ortadan kaldırılmasına yönelik reaksiyonlar hakkında bkz. Halil İnalcık, "Tanzimat'ın Uygulanması ve Sosyal Tepkiler”, Belleten, c. 28, Sayı: 112, Ankara 1964, s. 632vd. Bu hanedanlardan biri olup henüz üzerinde belirli bir çalışma yapılmamış olan Cennetzâdeler Erzurum'da (Bkz. Haydar Çoruh, Temettüat Defterlerine Göre Erzurum Şehri (1845), Hatay 2018), Bedirhan Bey Van'da (Bkz. Cabir Doğan, Cizre ve Bohtan Emiri Bedirhan Bey (1802-1869), (Doktora Tezi, AKÜ, SBE), Afyonkarahisar 2010) ve nihayet Tuzcuoğulları Trabzon ve havalisinde (Bkz. Münir Aktepe, "Tuzcu-oğulları İsyanı", Tarih Dergisi, c. 3, Sayı: 5-6, İstanbul 1953, s. 21-52.
}

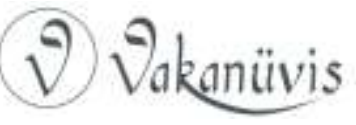


Osmanlı Devleti, Tanzimat Fermanı'nın ilanına kadar daha ziyade vergi içerikli sayımlar yapmaya özen gösterirken, bu fermana göre şekillenen yeni toplum düzeninin ortaya çıkardığı problemlerin üstesinden gelebilmek için daha farklı bir nüfus tespit sistemine gidilmesi gerektiğinin bilincine varmıştır. Bu tarihe kadar hane reisinin öne çıkarıldığı sayım sistemi terk edilmiştir. Bu durum özellikle 1890 sonrası yapılan sayımlara yansımıştır ve hane reisi olmasalar da imparatorluğun büyük bir bölümünde kadınlar, çocuklar ve yaşlılar da sayımın bir parçası yapıımıştı ${ }^{24}$. Bu itibarla kadınlar ilk defa 1893 tarihli nüfus sayımında sayılmıştır ${ }^{25}$.

Osmanlı nüfus kayıtları, Tanzimat sonrasında öncekilere nazaran Müslümanlar açısından olduğu kadar Hıristiyanlar açısından da önemli veriler sunmaktadır. Devlet eliyle yapılan nüfus sayımlarında gündemi vergi ve askerlik meselelerinin oluşturması, nüfusun özellikle kadın ve çocuklarla ilgili kısımlarında veri kayıplarına sebep olmuştur. Aynı şeyi Hıristiyan nüfusun sayımında da görmek mümkündür. Ancak Hıristiyan nüfusun kendi dini kurum ve kuruluşları tarafından da sayılıyor olması bu kitleye ait kadın ve çocuklarla ilgili kayıtlara ulaşmayı mümkün kılabilmektedir. Hıristiyan nüfusun tetkikindeki verimliliğin bir diğer sebebi de cizye vergisinin özellikle son dönemde devlet hazinesinde önemli bir yer tutmaya başlamasıdır. Buradan gelir kaybına uğramak istemeyen devletin yanı sıra Hristiyan liderlerin de kendi cemaatlerini daha fazla göstermek adına bu tür kayıtları daha titiz tuttukları söylenebilir ${ }^{26}$.

\section{Antakya Kazası Cizye Tahrirleri}

Osmanlı İmparatorluğu'nda yapılan nüfus sayımlarına ait 20 bin defter arasından Antakya'ya ait defterler tetkik edildiğinde defterlerin daha ziyade nüfus yoklama defterleri olduğu anlaşımaktadır. Bu defterler arasında yoğun olmasa da ardışık tarihlerde tutulmuş olan cizye defterlerinin varlığı da dikkat çekmektedir. 1694, 1842, 1843, 1844, 1846 yıllarına ait cizye defterlerinin yanı sıra 1848'de de bir sayım yapıldığına dair belgeler mevcuttur. Cizye tahririnin bu şekilde bir yıllık

\footnotetext{
24 M. Güneş, a.g.m., s. 228.

25 M. Güneş, a.g.m., s. 228.

${ }^{26}$ Dinç, a.g.m., s. 161.
}

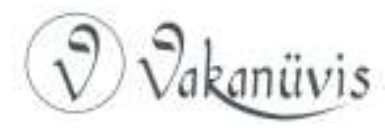


ara ile yapılması olağanüstü bir duruma işaret etmektedir ki, Tanzimat uygulamaları bu olağanüstü dönemi oluşturmaktadır. Oysaki cizye tahrirlerinin her üç yılda bir yapıldığı ve bu uygulamaya da "nev-yâfte yılı" adı verildiği bilinmektedir. Bu uygulamada genel bir teftiş yapılarak mükellefiyeti düşmüş olan ölülerin öncelikle hesaptan düşüldüğü anlaşılmaktadır. Akabinde gözden kaçıp deftere işlenmeyen ve mükellefiyet kazananların kaydı (nev-yafte) hususlarını içerirdi ${ }^{27}$.

Kara, 11-20 Safer (07 Ocak 1849) tarihli bir belgeden elde ettiği bilgilere dayanarak imparatorluk çapında yapılan sayım sonrasında sıranın Arabistan ve havalisine geldiğini belirterek, Antakya'nın Arabistan Ordusu'na bağlı Halep sancağı ile tahrir edilmiş olabileceğini ileri sürmektedir ${ }^{28}$. XIX. Yüzyılın ikinci yarısında ise 1867 yılında yapılımış bir başka nüfus sayımından Cevdet Paşa bahsetmektedir. Paşa, idari ve askeri düzenlemelerden daha iyi sonuç alabilmek adına söz konusu yılda Müslüman ve gayrimüslim nüfus hakkında önemli bilgiler vermektedir. Bu nüfus sayımında Antakya kazasında 8.775 hane Müslüman, 1.129 hane de gayrimüslim bulunduğunu ifade etmektedir ${ }^{29}$.

XIX. yüzyıla ait nüfus ve cizye defterlerinde vergi mükellefleri hakkında verilen bilgiler arasında en önemli husus, mükellefin yaptığı ticari, sınai veya mesleki işin yanı sıra hangi sınıf cizyeye tabi olduğunun belirtilmiş olmasıdır.

\section{Tarihli Cizye Tahriri}

\section{Defterin Durumu}

Başbakanlık Osmanlı Arşivi, Bâb-ı Ali Cizye Muhasebesi (D.CMH), nr. 120/26681 tasnifine kayıtlı defter ikisi boş olmak üzere toplam 20 sayfadan oluşmaktadır. 1694/1106 tarihli bu defterin kapak kısmında “harir-i be-ma'rifetü'l-fakrü'l-istihâk-ı te'âla Muhammed Said e's-sâfi Bikrâs ma'a İskenderun" ibaresi yer almaktadır. Yani tahriri yapan kişinin Muhammmed Said olduğu ifade edilmektedir. Defter iki bölümden oluşmaktadır. İlk bölüm Antakya ve çevresini, ikinci bölüm ise Beylan kazasındaki gayrimüslimlerin cizyelerini ihtiva etmektedir. Defterin ilk

\footnotetext{
27 Zülfiye Koçak, a.g.m., s. 224.

${ }^{28}$ Kara, , "XIX. Yüzyılın İlk Yarısında Antakya'da Yerleşme Ve Nüfus", s. 7.

${ }^{29}$ Adem Tutar, "Osmanlı Döneminde Antakya'nın Nüfusu ve Dini Yapısı (1860-1921)", Fırat Üniversitesi Ilahiyat Fakültesi Dergisi, Sayı: 5, Elazığ 2000, s. 71.
}

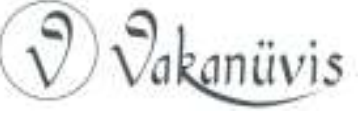


bölümünün ilk sayfasında "bin yüz altı senesinin kefereleri cizyesi beyânıdır." denilmektedir. Bu bölümün devamında "karye-i Suriye zimmileri (s.2)", "Cünte kefereleri (s. 39)", "Keseb kefereleri (s.3)", "Ordu kefereleri (s. 4)", "Hacı Habiblü kefereleri (s. 4)", "Yoğunoğluk kefereleri (s. 5)", "Zeytuniye kefereleri (s. 6)" ve "Kâbusiye kefereleri (s. 6)"nden bahsedilmektedir.

Defterin devamında Antakya ve bağlı mahalleler yer almaktadır. Bu mahalleler nefs-i Antakya, Günlük, Mukbil, Mahsen, Sarı Mahmud, Kantara, Dut, Habibü'n-Neccar, Dört Ayak, Sofilar, Cami-i Kebir, Şenbek (s. 8-11)'dir. Defterin bu ilk bölümünün son kısmında ise Antakya'daki "Ermeni keferesi (s. 12)" ve "Yahudi keferesi (s. 13)" ne ait verilere yer verilmiştir. Bu kısmın devamında ise "Antakya'da işleyen perakende zimmiler (s. 14)", "Gelip geçen kefere cizyeleri (s. 15)" yer almaktadır. Defterin ikinci bölümünde Beylan kazasına bağlı mahallelerdeki gayrimüslimlere ait cizyeler verilmiştir. Ancak Beylan kazasının tahriri konumuz dışında kaldığından bir fikir vermesi amacıyla bu bilgiler dipnotta zikredilecektir ${ }^{30}$.

Defterin son kısmında bazı eksikliklerin olduğunu ifade etmek yerinde olacaktır. Antakya ve çevresinde yer alan mahalle ve nahiyelerin yer aldığı ilk bölümünün ikinci sayfasında "Karye-i Cünte kefereleri" kaydedilmiştir. Bu kısımda bir önceki sayfada olduğu gibi bir mizana yer verilmemiştir.

\section{Tarihli Cizye Tahririne Göre Antakya ve Çevresinde Nüfus}

1691 tarihli cizye reformunun hemen akabinde 1694 tarihinde yapılan bu cizye tahriri Antakya ve çevresinde devletin hâkimiyetine işaret etmektedir. Sonraki yıllarda gerek nüfus ve vergi sayımları gerekse cizye tahrirleri bölge insanı arasında isyanlara veya itirazlara sebep olurken, bu tahrir sebebiyle söz konusu yıllarda bölgede herhangi bir olumsuz olayın cereyan etmemiş olması önemli bir veridir. Ancak bu tarihten kısa bir süre sonra bölgeye gelen Cizvit ve Kapuçin tarikatları

\footnotetext{
30 Defterin ikinci bölümünü oluşturan Beylan kazasına ait cizye defterinde üç ayrı mahallede tahrir yapılmıştır. Kilise mahallesinde bulunan gayrimüslimlere ait cizyedarlar 130 kişi (BOA, D.CMH, nr. 120/26681, s. 16-17), Barrak (Bakras olabilir) mahallesinde ise 45 kişi (BOA, D.CMH, nr. 120/26681, s. 17-18), Hammare mahallesin de ise 115 cizye mükellefi tespit edilebilmektedir (BOA, D.CMH, nr. 120/26681, s. 18-19).
}

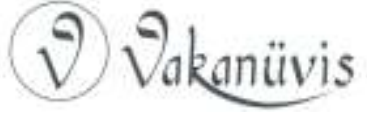


gayrimüslimleri devlet aleyhinde kullanarak bölgede karışıklıklara ve huzursuzluklara sebep olmuşlardır ${ }^{31}$.

1694 tarihli defter incelendiğinde vergi mükelleflerinin açık bir şekilde kişi üzerinden tahrire tabi tutulduğu görülebilmektedir. Cünte karyesinde 25, Keseb karyesinde $30^{32}$, Ordu karyesinde 10, Hacı Habiblü karyesinde $50^{33}$, Yoğunoluk karyesinde $48^{34}$, Zeytuniye karyesinde 32 ve Kâbusiye karyesinde $40^{35}$ olmak üzere toplam 235 kişi cizye mükellefi tespit edilmiştir. Defterin devamında "nefs-i Antakya'ya bağlı mahallelerden Kastal'da 75, Günlük'te 21, Mukbil'de 6, Mahsen'de 8, Sarı Mahmud'da 9, Kantara'da 6, Tut'da 5, Cebel-i Neccar'da 15, Dört Ayak'ta 5, Sofilu'da 23, Cami-i Kebir'de 8 ve Şenbek'te ise 9 olmak üzere toplam 190 kişi cizye mükellefi vardı ${ }^{36}$.

Antakya şehrinde bulunan Ermeni taifesinin 40 ve Yahudilerin ise 36 olmak üzere toplam 76 kişi cizye evrakı olduğu tespit edilmiştir ${ }^{37}$.

“Nefs-i Antakya'ya gelip giden zimmilerde 60 kişiydi. Bazı kayıtlarda cizye mükelleflerinin nereden geldikleri de belirtilmiştir. Buna göre Antakya'ya gelip gidenlerden 11 'inin "Acem" yani İranlı olduğu anlaşılmaktadır ${ }^{38}$.

Osmanlı Devleti'nde İranlı tüccardan cizye alınması eski bir gelenektir. İran'dan Osmanlı topraklarına gelen tacirlerin çoğunlukla Ermeni olması bu uygulamanın yüzyıllarca devam etmesine sebep olmuştur ${ }^{39}$. Dikkat çeken bir husus ise incelenen defterlerden 1842 ve sonrası cizye tahrirlerinde kişinin mesleğine atıfta bulunulurken, 1694 cizye tahririnde meslekleri belirtilmemiş ve sadece kişinin eşkâline yer verilmiştir. Diğer taraftan 1694 tarihli cizye tahririnde dikkat çeken bir diğer eksiklik mükelleflerin ödemekle yükümlü oldukları cizye

\footnotetext{
${ }^{31}$ Haydar Çoruh, “Melkit Patrikliğinin Kuruluşu Ve Osmanlı Devleti, Papalık Ve Fransa İle iliş̧kileri (1853-1919)", Türk Kültürü Incelemeleri Dergisi, Sayı: 39, İstanbul 2018, s. 84 vd.

32 BOA, D.CMH, nr. 120/26681, s. 3.

33 BOA, D.CMH, nr. 120/26681, s. 4.

${ }^{34}$ BOA, D.CMH, nr. 120/26681, s. 5.

35 BOA, D.CMH, nr. 120/26681, s. 6.

${ }^{36}$ BOA, D.CMH, nr. $120 / 26681$, s. 8-11.

${ }^{37}$ BOA, D.CMH, nr. 120/26681, s. 12-13.

${ }^{38}$ BOA, D.CMH, nr. 120/26681, s. 14-15.

39 inalcık, a.g.mad., s. 47.
}

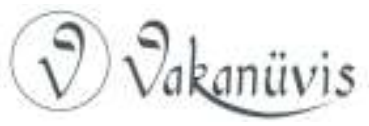


miktarlarına atıf yapıımamış olmasıdır. Defterin hiçbir aşamasında a'lâ, evsât ve ednâ cinsinden bir meblağa tesadüf edilememiştir. Sadece defterin ikinci sayfasının sonunda "...eski sarı tezkere adet: 37 olup senei cedid ... verildi: 23, toplam 60 ..... verildi" şeklinde tam olarak okunamamakla beraber küçük bir icmâl verilmiştir ${ }^{40}$. Ancak defterin tamamı incelendiğinde bu icmâlin diğer sayfalarda tekrarlanmadığı görülmektedir ki, bu da defterin bir başka defterden düşmüş bir parça olabileceği intibaını uyandırmaktadır.

Kaynaklar cizye tahrirlerinin esasında 1694 'den sonra 1696, 1743, $1804,1816,1824,1827,1829$ ve 1834 yıllarında peyderpey yapıldığı bilgisini vermektedir ${ }^{41}$. Ancak bu genel geçer durum Antakya için söz konusu değildir. Antakya 1694-1842 yılları arasında Halep Sancağı'nın bir parçası olduğundan cizye tahrirlerinde müstakil bir tahrire rastlanamamıştır. Bunun sebebi olarak söz konusu tarihlerde Antakya'nın Halep'e bağıı bir kaza olması gösterilebilir.

\section{Tarihli Cizye Tahriri}

1842 yılına ait ML.VRD.CMH, nr. 138'de tasnif edilmiş olan defter Kara tarafından yayınlanmıştır. Bu sebeple burada sadece defterin durumu hakkında bilgi verilecek ve defterde yer alan icmâle dikkat çekilecektir ${ }^{42}$.

\section{Defterin Durumu}

Otuz bir sayfadan oluşan defter "bin iki yüz elli sekiz senesi itibariyle derûn-i Antakya ve karyelerinde vâkı' cizye defteridir. Ber-vech-i atîyü'zzikr dermeyân olunur" şeklindeki bir girişten sonra "an-taifetü'r-Rum bâ-Antakya" ifadesiyle genel bir cetvel oluşturulmuştur. 1842 tarihinden sonra 1843, 1844, 1846 tarihli defterler düzenlenmiştir. 1842 tarihli defter diğerleriyle aynı düzene sahiptir. Defterdeki genel cetvel a'lâ, evsât, ednâ, nâm, veled, şöhret, san'at, mütemekkin, sinin, boy,

\footnotetext{
${ }^{40}$ BOA, D.CMH, nr. 120/26681, s. 2.

41 İnalcık, a.g.mad., s. 47. 1691'den sonra yapılan cizye reformlarının Kıbrıs üzerinden tetkiki hakkında bkz. Haydar Çoruh, Osmanlı'da Değişim Rüzgârları (Azınlıkların Yükselişi), Mustafa Kemal Üniversitesi Yayınları, No: 45, Hatay 2013, s. 50 vd.

42 Adem Kara, XIX. Yüzyılın IIlk Yarısında Antakya (1800-1850), (Doktora Tezi, A.Ü., SBE), Ankara 2004, s. 27 vd; aynı müellif, "XIX. Yüzyılın Illk Yarısında Antakya'da Yerleşme ve Nüfus", OTAM (Ankara Üniversitesi Osmanlı Tarihi Araştırma ve Uygulama Merkezi) Dergisi, Sayı: 17, Ankara 2005, ss. 1-14.
}

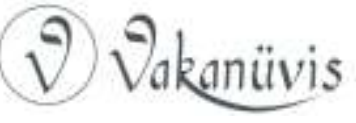


sakal, bıyık, göz ve kişi numarası gibi özellikleri kaydedecek şekilde düzenlenmiştir. 1694 tarihli cizye defterinde verilen kişi ifadesinin bu ve sonraki defterlerde numara şeklinde verilmiş olması da ayrı ve yeni bir özellik olarak dikkat çekmektedir.

Tablo 1. 1842 Tarihli Tahrire Göre Antakya ve Tabi Karyelerden Elde Edilen Cizye Gelirleri (İcmâl)

\begin{tabular}{|l|l|l|l|l|l|}
\hline Antakya Yerleşim Yerleri & Kişi/Kişi & A'lâ & Evsât & Ednâ & $\begin{array}{c}\text { Toplam } \\
\text { Vergi }\end{array}$ \\
\hline Derun-i Antakya & & & & & \\
\hline Taife-i Rum & 246 & 15 & 130 & 101 & 6.315 \\
\hline Taife-i Ermeni & 35 & & 19 & 16 & 810 \\
\hline Taife-i Yahudi & 44 & 1 & 24 & 18 & 1.050 \\
\hline Nahiye-i Kuseyr tabii Karye-i Suriye & 83 & & 66 & 15 & 2.205 \\
\hline Nahiye-i Kuseyr tabii Karye-i Cünte & 72 & & 54 & 18 & 1.890 \\
\hline Nahiye-i Akra tabii Karye-i Ordu & 63 & & 43 & 20 & 1.590 \\
\hline Nahiye-i Akra tabii Karye-i Keseb & 262 & & 202 & 60 & 6.960 \\
\hline $\begin{array}{l}\text { Nahiye-i Süveydiye tabii Karye-i } \\
\text { Zeytuniye }\end{array}$ & 325 & 2 & 214 & 109 & 8.235 \\
\hline $\begin{array}{l}\text { Nahiye-i Süveydiye tabii Karye-i } \\
\text { Kabusiye }\end{array}$ & 81 & 1 & 59 & 21 & 2.145 \\
\hline $\begin{array}{l}\text { Nahiye-i Süveydiye tabii Karye-i } \\
\text { Yoğunoluk }\end{array}$ & 303 & & 231 & 72 & 8.010 \\
\hline $\begin{array}{l}\text { Nahiye-i Süveydiye tabii Karye-i Hacı } \\
\text { Habiblu }\end{array}$ & 213 & & 172 & 40 & 5.790 \\
\hline \begin{tabular}{l} 
Toplam \\
\hline
\end{tabular} & $\mathbf{1 . 7 2 7}$ & $\mathbf{1 9}$ & $\mathbf{1 . 2 1 4}$ & $\mathbf{4 9 0}$ & $\mathbf{4 5 . 0 0 0}$ \\
\hline
\end{tabular}

\section{Tarihli Cizye Tahririne Göre Antakya ve Çevresinde Nüfus}

Tablo 1. de görüldüğü üzere defterin bu ilk bölümünde Antakya'daki Rum taifesine ait toplam 246 hanede 15 a'lâ, 130 evsât, 101 ednâ vergi mükellefi olduğu ve bu mükelleflerden 6.315 kuruş cizye tahsil edildiği tespit edilebilmektedir ${ }^{43}$. Defterin devamında Antakya'daki Yahudilere yer verilmiştir. Bunlar arasında a'lâ sınıfından herhangi bir mükellefe tesadüf edilmemektedir. Yahudilerin toplamı 44 kişidir. 24 evsât ve 18

${ }^{43}$ BOA, ML. VRD. CMH, nr. 138, s. 1-5.

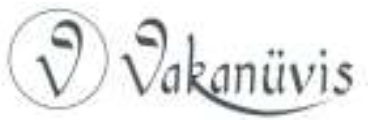


ednâ vergi mükellefinden 1.050 kuruş tahsil edilmiştir ${ }^{44}$. Antakya'da 35 Ermeni cizyedâr bulunmaktaydı. Bunların 19'u evsât ve $16^{\prime}$ sı ise ednâ olup, bunlardan 810 kuruş cizye alınmaktayd $\iota^{45}$.

Defterin yedinci sayfasından sonra karyelere (köy) yer verilmiştir. Kuseyr nahiyesine bağlı Suri karyesinde etnik kökeni belirtilmemiş toplam 60 evsât ve 15 ednâ vergi mükellefi bulunmaktaydı. Bu mükelleflerin Halep hazinesine gönderdikleri vergi 2.205 kuruş idi ${ }^{46}$. Kuseyr nahiyesine bağı Cünte karyesinde ikamet eden 72 kişiden 54'ü evsât ve 18 'i ednâ vergi mükellefiydi. Bunlardan 1.840 kuruş cizye tahsil edilmiştir ${ }^{47}$.

Cebel-i Akra (merkez Antakya'nın güneyindeki bazı köyler, Altınözü ve Yayladağı köylerinden bazıları ${ }^{48}$ )'ya bağlı Ordu karyesinde ise 63 kişi kaydedilmiştir. Bu mükelleflerden 43'ü evsât ve $20^{\prime}$ si ise ednâ idi ${ }^{49}$. Aynı nahiyenin Keseb karyesinde ise 262 kişi mükellef bulunmaktaydı. Bu mükelleflerden 202'si evsât ve 60'ı ise ednâydı. Bu mükelleflerin hazineye gönderdiği meblağ ise 6.960 kuruştu $^{50}$. Süveydiye nahiyesi Zeytuniye karyesinde bulunan 325 kişinin 1'i a'lâ, 214'ü evsât ve 104'ü ednâ sınıftandı. Bu mükelleflerin hazineye gönderdiği vergi miktarı ise 8.235 kuruştur $^{51}$. Süveydiye nahiyesi Kabusiye karyesinde ise 81 kişiden 1'i a'lâ, 59'u evsât ve $21^{\prime} i$ ednâ idi. Bu mükelleflerin hazineye ödediği toplam vergi miktarı ise 2.145 kuruştur $^{52}$. Süveydiye nahiyesi Yoğunoluk karyesindeki 303 kişiden 231'i evsât ve 72'si ednâ idi. Bu vergi mükellefleri hazneye 8.010 kuruş ödeme yapmıştır ${ }^{53}$. Süveydiye nahiyesi Hacı Habiblü karyesindeki 213 vergi mükellefinden 173'ü evsât ve 40'ı ise ednâ sınıftan olup Halep hazinesine 5.790 kuruş vergi verdikleri tespit edilmiştir ${ }^{54}$.

\footnotetext{
${ }^{44}$ BOA, ML. VRD. CMH, nr. 138, s. 5-6.

${ }^{45}$ BOA, ML. VRD. CMH, nr. 138, s. 6-7.

${ }^{46}$ BOA, ML. VRD. CMH, nr. 138, s. 7-8.

47 BOA, ML. VRD. CMH, nr. 138, s. 8-9.

48 Kara, a.g.t., s. 11.

${ }^{49}$ BOA, ML. VRD. CMH, nr. 138, s. 10.

50 BOA, ML. VRD. CMH, nr. 138, s. 11-15.

${ }^{51}$ BOA, ML. VRD. CMH, nr. 138, s. 15-20.

52 BOA, ML. VRD. CMH, nr. 138, s. 21-22.

53 BOA, ML. VRD. CMH, nr. 138, s. 22-27.

${ }^{54}$ BOA, ML. VRD. CMH, nr. 138, s. 27-30.
} 
1842 tarihli cizye defterine göre Antakya ve tabi nahiyelerde toplam 1.727 hanede 19 a'lâ, 1.214 evsât ve 490 kişi de ednâ cizye vergisi veren vergi mükellefi bulunmaktadır. Bu vergi mükelleflerini Ö. L. Barkan'ın ortalama hane sayısı $5^{55}$ ile çarptığımızda Antakya'daki gayrimüslim nüfusun 8.635 kişi olduğunu söylemek mümkündür.

\section{Tarihli Cizye Tahriri}

\section{Tarihli Defterlerin Durumu}

9 Zilhicce 1259/31 Aralık 1843 tarihli ve BOA, ML.VRD.CMH, nr. 215/02-3'te kayıtlı defter sadece dört sayfadan ibarettir. Ancak yapılan inceleme sonucunda bu defter ile BOA, MAD df. 20525 numaralı defterin aynı deftere ait iki ayrı parça olduğu anlaşılmıştır. Dolayısıyla esas defter BOA, MAD df. 20525 numaralı defterdir. Bu defterin eksik olan 1.-3. sayfaları ve 31. Sayfası 4 ayrı sayfadan bir defter oluşturularak BOA, ML.VRD.CMH, nr. 215/02-3 adı altında tasniflenmiş olduğu tespit edilmiştir. Bu defterin birinci sayfasında "1259 senesine mahsuben Antakya ve havi olduğu kuraların emval-i cziye-i şeriyye defteridir. Bervech-i ati zikr olunur." ${ }^{56}$ ifadesi yer almaktadır. Defterin düzeni 1694/1106 tarihli defterden oldukça farklıdır. Cetvel şeklinde düzenlenmiş olan defter, "Nefs-i Antakya taife-i Rum" ibaresiyle başlamaktadır.

\section{a) 1843 Tarihli Cizye Tahririne Göre Antakya ve Tabii Mahallerde Meslekler}

1830 'da ilk modern nüfus sayımının yapılması, nüfus sayım sisteminde yeni gelişmelerin olmasını sağlamıştır. Nüfus defterleri bu tarihe kadar Tapu Tahrir sistemiyle işlenirken bundan sonra cetveller düzenlenmeye başlanmıştır. Bu kapsamda yapılan 1840 ve sonrası nüfus tahrirlerinin de bu cetvellere uygun olarak yapıldığını söylemek mümkündür. Tahrirde öncelik hane sahibinin hangi cemaate mensup olduğunu belirlemeye verilmiştir. Mükellefin ödeyeceği vergi miktarı, eşkâli ve hane numarasının işlendiği cetveller XIX. yüzyıl boyunca hemen hemen aynı niteliklere sahip olmuştur.

555 rakamı için Bkz. Ömer Lütfi Barkan, "Tarihi Demografi Araştırmaları ve Osmanlı Tarihi", Türkiyat Mecmuası, Sayı: X, 1953, s. 1-26.

${ }^{56}$ BOA, ML.VRD.CMH, nr. 215/02-3, s. 2.

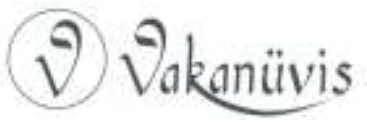


Tablo 2'de görüleceği üzere birbirinden kopmuş olan iki defterden oluşan 1843 cizye tahririnden çürümüş yerlerindeki bilgilere ulaşılamamakla beraber toplam 64 çeşit sanattan en az birine tabi 1.525 meslek erbâbı tespit edilmiştir. Bu mesleklerin en yoğun olduğu yerler Süveydiye'ye bağlı Hacı Habiblü, Yoğunoluk, Zeytuniye ve Cebel-i Akra'ya bağlı Keseb karyesidir. Bu karyelerde bulunan sanatkârlar arasında en fazla çulha/çulfa (121 kişi), çiftçi (373 kişi) ve fail (526 kişi)'e rastlanmaktadır. Bunların dışında 30-50 kişi arasında yer alan meslek erbâbı abacı, bazergân, çerçi, köşker/kefişker, mimar ve terzidir. Meslek grupları arasında 10-30 kişi civarında olanlar arasında ise aciz, attâr, avatlı, huddâm, kalaycı, kazancı, kuyumcu, neccâr ve semerci yer almaktadır. Diğer meslek dallarının tamamı ise 1-10 kişi arasındadır.

Antakya, Süveydiye, Cebel-i Akra ve Kuseyr beldelerindeki karyelerdeki vergi mükelleflerinin tabi oldukları meslek dalları yoğunluk açısından incelendiğinde en fazla meslek erbâbının 261 kişi ile Süveydiye'ye bağlı Yoğunoluk karyesinde olduğu söylenebilir. Bu karyedeki nüfusun (311 kişi) yaklaşık \%80'inin bir mesleğe sahip olduğunu söylemek mümkündür. Yoğunluk açısından bu beldeyi 257 kişi ile Antakya'da ikamet eden Rum taifesi, 238 kişi ile Süveydiye nahiyesi Zeytuniye karyesi, 235 kişi ile Cebel-i Akra'ya tabi Keseb karyesi ve 188 kişi ile Süveydiye nahiyesi $\mathrm{Hacı}$ Habiblü karyesi takip etmektedir. Bunların dışında kalan Antakya Ermeni taifesi, Yahudi taifesi, Cebel-i Akra Ordu karyesi ise 30-50 kişi arasında yoğunluğa sahiptir. Süveydiye Kabusiye karyesi, Kuseyr Cünte karyesi ve Suriye karyeleri ise 60 ve 60 'tan fazla yoğunluktadır.

Tablo 2. 1843 Tarihli MAD. 20525 ve ML.VRD.CMH, 215 nolu Defterlere Göre Antakya ve Çevresinde Meslekler (Hane)

\begin{tabular}{|c|c|c|c|c|c|c|c|c|c|c|c|c|c|}
\hline 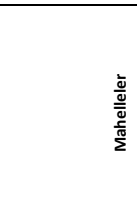 & 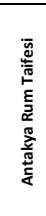 & 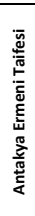 & 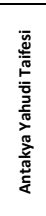 & 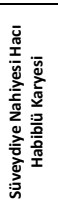 & 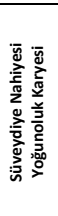 & 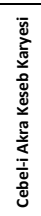 & 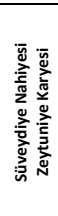 & 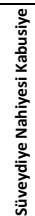 & 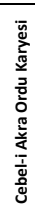 & 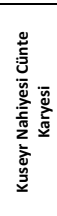 & 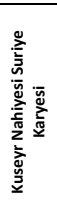 & 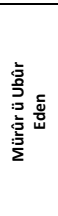 & \\
\hline Abacl & 29 & 2 & & & & & 6 & & 3 & & & & 40 \\
\hline Aciz & & & & & 2 & & 11 & 1 & & & & & 14 \\
\hline Attar & 9 & & 19 & & & & & & & & & & 28 \\
\hline Avatlı & 3 & 3 & & 2 & 1 & 1 & 2 & 5 & & & 3 & 1 & 21 \\
\hline Azab & & & & & & & 1 & & 1 & & & & 2 \\
\hline
\end{tabular}




\begin{tabular}{|c|c|c|c|c|c|c|c|c|c|c|c|c|c|}
\hline Bahri & & & & & & & & & & & & 1 & 1 \\
\hline Bakkal & 5 & 1 & & & & & & & & & & & 6 \\
\hline Balatçı & & & & & 1 & & & & & & & & 1 \\
\hline Basmacı & & 4 & & & & & & & & & & & 4 \\
\hline Baytar & 5 & & & & & & 1 & & & & & & 6 \\
\hline Bazergan & 22 & & 13 & & & & & & & & & & 35 \\
\hline Berber & & 1 & & & & & 4 & & 1 & & 1 & & 7 \\
\hline Boyacı & 1 & & & 1 & 1 & 2 & 1 & & 1 & & & & 7 \\
\hline Büyücü & & & & 1 & & & & & & & & & 1 \\
\hline Culfa & & & & & & & 2 & & & & & & 2 \\
\hline Çerçi & 6 & & 10 & & & 1 & & & & 1 & & 14 & 32 \\
\hline Çiftçi & & & & 38 & 77 & 132 & 21 & 47 & 1 & 38 & 19 & & 373 \\
\hline Çoban & & & & & & & & & & 1 & 2 & & 3 \\
\hline Çulha & 1 & 1 & & 2 & 1 & 53 & 20 & & 3 & 6 & 36 & & 123 \\
\hline Değirmenc & & & & & 1 & & & & & & & & 1 \\
\hline Eskici & 2 & & & & & 3 & & & & 1 & & & 6 \\
\hline Fail & 9 & 3 & & 139 & 168 & 30 & 145 & 12 & & 18 & 2 & & 526 \\
\hline Halife & 1 & & & & & & & & & & & & 1 \\
\hline Hallaç & & & & & & & 3 & & 1 & & 1 & & 5 \\
\hline Hancı & & 1 & & & & & & & & & & & 1 \\
\hline Harami & & & & & & & 1 & & & & & & 1 \\
\hline Hayik & & & & & & & & & & & 1 & & 1 \\
\hline Havvat & & & & & 1 & & 1 & 1 & & & & & 3 \\
\hline Hekim & & & & & & & & & 1 & & & & 1 \\
\hline Huddam & 3 & & & & & & 6 & & & & & 3 & 12 \\
\hline İhtiyar & & & & & 1 & & & & & & & & 1 \\
\hline Kalaycı & 7 & 6 & & & & 2 & & & 1 & & & & 16 \\
\hline Kalıpçı & & 2 & & & & & 2 & & 3 & & & & 7 \\
\hline Kalyoncu & & & & & & & & & & & & 2 & 2 \\
\hline Kapıcı & 1 & & & & & & & & & & & & 1 \\
\hline Kattan & 1 & & & & & & & & & & & & 1 \\
\hline Katip & & & & & & & & & & 1 & & & 1 \\
\hline Kazmacı & & & & & 2 & & & & & & & & 2 \\
\hline Kazancı & 2 & 2 & & & 3 & 1 & & & & & & & 8 \\
\hline Kazzaz & 12 & & & & & & & & & & & & 12 \\
\hline Kefişker & & & & & & 10 & 1 & & 21 & & 1 & 1 & 34 \\
\hline Kınacı & 1 & & & & & & & & & & & & 1 \\
\hline Köhne & & & & 3 & 1 & & 2 & & & 1 & & & 1 \\
\hline Kuyumcu & 15 & 10 & & & & & & & & & & 1 & 26 \\
\hline Kürkçü & 2 & & & & & & & & & & & & 2 \\
\hline Mekkari & & & & & & & 3 & & & 1 & & 1 & 5 \\
\hline Meşinci & & & & & & & & & 1 & & & & 1 \\
\hline Mimar & 51 & & & & & & 1 & & 1 & 1 & 1 & & 55 \\
\hline Mübeyyiz & & & & 1 & & & & & & & & & 1 \\
\hline
\end{tabular}




\begin{tabular}{|l|r|r|r|l|l|l|r|r|r|r|r|l|l|}
\hline Naalband & 1 & & & & & & 1 & & & & & 2 \\
\hline Necc ar & 14 & & 4 & & & & & & & & & & 18 \\
\hline Odabaşı & & 1 & & & & & & & & & & & 1 \\
\hline Rai & & & & & 1 & & 5 & & & & & & 6 \\
\hline Sabi' & & & & 1 & & & & & & & & & 1 \\
\hline Saraydar & 3 & & & & & & & & & & & & 3 \\
\hline Semerci & 10 & & & & & & & & & & & & 10 \\
\hline Serpefil & & 1 & & & & & & & & & & & 1 \\
\hline Sibağ & & & & & & & & & 2 & & & \\
\hline Simsar & 1 & & & & & & & & & & & 2 \\
\hline Tarakçı & 2 & & & & & & & & & & & & 2 \\
\hline Terzi & 33 & & & & & & & & & & & & 33 \\
\hline Tuzcu & 1 & & & & & & & & & & & & 1 \\
\hline Tütüncü & 4 & & & & & & & & & & & & 4 \\
\hline Zummar & & & & & & & 1 & & & & & & 1 \\
\hline Toplam & $\mathbf{2 5 7}$ & $\mathbf{3 8}$ & $\mathbf{4 6}$ & $\mathbf{1 8 8}$ & $\mathbf{2 6 1}$ & $\mathbf{2 3}$ & $\mathbf{2 3}$ & $\mathbf{6 6}$ & $\mathbf{4 1}$ & $\mathbf{6 9}$ & $\mathbf{6 7}$ & $\mathbf{2 4}$ & $\mathbf{1 . 5 2 5}$ \\
\hline
\end{tabular}

\section{b) 1843 Tarihli Cizye Tahririne Göre Yerleşim Yerlerinden Elde Edilen Gelirler}

1843 tarihli cizye tahririne göre Antakya mahallelerinden elde edilen cizye gelirinin çoğunluğu 267 kişi ile Rumlara aittir. Bunu 46 kişi ile Yahudiler, 38 kişi ile Ermeniler takip etmektedir. Bu üç taifenin hazineye gönderdiği cizye miktarı 8.535 kuruştur. Süveydiye nahiyesi Zeytuniye karyesinden 8.130 kuruş cizye geliri tedarik edilmiştir. Diğerleri sırasıyla Yoğunoluk karyesinden 8.085 kuruş, Hacı Habiblü karyesinden 5.790 kuruş ve Kabusiye karyesinden ise 2.025 kuruş cizye geliri elde edilmiştir. Cebel-i Akra nahiyesine Keseb ve Ordu karyelerinden ise 8.340 kuruş gelir elde edilirken Kuseyri nahiyesi Suriye ve Cünte karyelerinden ise 4.065 kuruş vergi tahsil edilmiştir (Bkz. Tablo 3).

1843 yılında Antakya'ya 24 kişi gelip gitmiştir. Bu yabancılar 510 kuruş cizye vergisi öderlerken, bölgeye 1 adet de evsât cizye mükellefinin geldiği belirlenmiştir. Bundan tahsil edilen 30 kuruşluk vergi ile bu dört nahiyeden Halep hazinesine gönderilen vergi 45.510 kuruş olmuştur (Bkz. Tablo 3). 
Tablo 3. 1843 Tarihli Tahrire Göre Cizye Gelirleri (İcmâl)

\begin{tabular}{|l|l|l|l|l|l|}
\hline Yerleşim Yerleri & Kişi/Kişi & $\begin{array}{c}\text { A'lâ } \\
\mathbf{6 0} \text { Krş. }\end{array}$ & $\begin{array}{c}\text { Evsât } \\
\mathbf{3 0} \text { Krş. }\end{array}$ & $\begin{array}{c}\text { Ednâ } \\
\mathbf{1 5} \text { Krş. }\end{array}$ & $\begin{array}{c}\text { Toplam Evrak } \\
\text { Bedeli }\end{array}$ \\
\hline Derûn-i Antakya & & & & & \\
\hline Taife-i Rum & 267 & 15 & 127 & 125 & 6.585 \\
\hline Taife-i Ermeni & 38 & & 18 & 20 & 840 \\
\hline Taife-i Yahudi & 46 & 2 & 22 & 22 & 1.110 \\
\hline Karye-i Suriye & 81 & & 66 & 15 & 2.205 \\
\hline Karye-i Cünte & 71 & & 53 & 18 & 1.860 \\
\hline Karye-i Ordu & 55 & & 37 & 18 & 1.380 \\
\hline Karye-i Keseb & 264 & & 200 & 64 & 6.960 \\
\hline Karye-i Zeytuniye & 327 & & 215 & 112 & 8.130 \\
\hline Karye-i Kabusiye & 78 & & 57 & 21 & 2.025 \\
\hline Karye-i Yoğunoluk & 311 & & 228 & 83 & 8.085 \\
\hline Karye-i Hacı Habiblu & 214 & & 172 & 42 & 5.790 \\
\hline Toplam & & & & & 44.970 \\
\hline Yabancı Zuhurat & 24 & & 10 & 14 & 510 \\
\hline Toplam & 1.776 & 17 & 1.205 & 554 & 45.480 \\
\hline Defa Yabancı Zuhurat & & & & & 30 \\
\hline Genel Toplam & $\mathbf{1 . 7 7 6}$ & $\mathbf{1 7}$ & $\mathbf{1 . 2 0 5}$ & $\mathbf{5 5 4}$ & $\mathbf{4 5 . 5 1 0}$ \\
\hline
\end{tabular}

c) 1843 Tarihli Cizye Tahririne Göre Mahallelerde Kayıtlı Vergi mükellefleri

1843 yılında Antakya, Süveydiye, Cebel-i Akra ve Kuseyr nahiyelerinde 1.751 vergi mükelleften cizye tahrir edildiği tespit edilmiştir ${ }^{57}$. Bunların cizye evrakına göre tasnifi yapıldığında Tablo 4'deki gibi bir durum söz konusudur. Tabloda da görüleceği üzere a'lâ cizye evrakına sahip mükellef sayısı sadece $16^{\prime}$ dır. Bu mükellefler Antakya'daki Rum (14 kişi) ve Yahudi (2 kişi) taifelerine mensuptur. Cizye tahririnin geneline bir göz atıldığında evsât cizye kâğıtlarının çoğunluğu teşkil ettiği tespit edilebilmektedir (Bkz. Tablo 4).

${ }^{57}$ Antakya'ya gelip gidenler ve sonradan tespit edilen 1 hane evsât cizye mükellefi bu toplamın dışındadır. 
Tablo 4. 1843 Tarihli Tahrire Göre Mahallelerdeki Vergi mükelleflerinin Cizyeleri

\begin{tabular}{|c|c|c|c|c|c|c|c|c|c|c|}
\hline \multirow[b]{2}{*}{ Mahalleler } & \multicolumn{3}{|c|}{$\begin{array}{l}\text { Antakya Rum } \\
\text { Taifesi }\end{array}$} & \multicolumn{3}{|c|}{$\begin{array}{l}\text { Antakya Yahudi } \\
\text { Taifesi }\end{array}$} & \multicolumn{3}{|c|}{$\begin{array}{l}\text { Antakya Ermeni } \\
\text { Taifesi }\end{array}$} & \multirow{2}{*}{\begin{tabular}{|l} 
Toplam \\
Nefer/Kişi
\end{tabular}} \\
\hline & A'lâ & Evsât & Ednâ & A'lâ & Evsât & Ednâ & A'lâ & Evsât & Ednâ & \\
\hline Cünte & & 41 & 38 & & & & & & & 79 \\
\hline Dört Ayak & & & & & & & & 4 & 7 & 11 \\
\hline Dut Dibi & & & 1 & & 7 & 5 & & 2 & 2 & 17 \\
\hline Günlük & & 2 & 1 & & & 6 & & & & 9 \\
\hline Kantara & 1 & 6 & 15 & 2 & 4 & 5 & & & & 33 \\
\hline $\begin{array}{l}\text { Kapu } \\
\text { Bölüğü }\end{array}$ & & & & & 7 & & & 2 & 2 & 11 \\
\hline Kastal & & 14 & 28 & & & & & & & 42 \\
\hline $\begin{array}{l}\text { Kılıççı } \\
\text { Sofilar }\end{array}$ & & & & & & & & & 1 & 1 \\
\hline Koca Abdi & & & & & 2 & 2 & & & & 4 \\
\hline Mahsen & 7 & 21 & 10 & & & 1 & & & & 39 \\
\hline Mukbil & 1 & 1 & & & & & & & & 2 \\
\hline Ömer Ağa & & & & & & & & & 1 & 1 \\
\hline Rikabiye & & & & & & & & 2 & 2 & 4 \\
\hline $\begin{array}{l}\text { Sarı } \\
\text { Mahmud }\end{array}$ & 4 & 35 & 15 & & & & & & & 54 \\
\hline Sofilar & & & 5 & & & & & 4 & 2 & 11 \\
\hline Şenbek & 1 & 2 & 1 & & 1 & 3 & & & & 8 \\
\hline $\begin{array}{l}\text { Tabi-i } \\
\text { Sofilar }\end{array}$ & & & & & & & & 4 & 3 & 7 \\
\hline $\begin{array}{l}\text { Toplam } \\
\text { Kişi }\end{array}$ & 14 & 122 & 114 & 2 & 21 & 22 & & 18 & 20 & 333 \\
\hline
\end{tabular}

1843 tarihli tahrir defterinde sayfalardaki çürümelerden kaynaklı problemlerden dolayı nüfus verilerinin bir kısmı okunamaz durumdadır. Bu sebeple nüfus miktarları karşılaştırıldığında 1842 tarihli tahrirden daha farklı sonuçlar elde edilmiştir. Tablo 4 incelendiğinde Antakya'nın toplam 20 mahallesinde sadece 14 kişi a'lâ cizye evrakına sahiptir. Bu mükellefler Kantara, Mahsen, Mukbil, Sarı Mahmud ve Şenbek mahallelerinde yaşayan Rum taifesine aittir. Bunların dışında Cünte, Günlük, Kantara, Kastal, Mahsen, Mukbil, Sarı Mahmud ve Şenbek

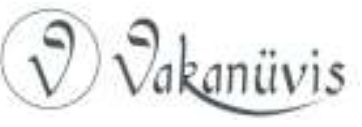


mahallelerinde 122 evsât evrak tespit edilmiştir. Cünte, Dut Dibi, Günlük, Kantara, Kastal, Mahsen, Sarı Mahmud, Sofilar ile Şenbek mahallelerinde ise 114 ednâ Rum mükellef bulunmaktaydı.

Antakya mahallelerindeki Yahudilerden sadece 2 kişi a'lâ cizye evrakına sahipti. Bunlar Kantara mahallesinde yaşamaktaydılar. 21 evsât evrak sahibi Yahudi ise Dut Dibi, Kantara, Kapu Bölüğü, Koca Abdi ve Şenbek mahallelerinde ikamet etmekteydi. Ermeniler ise sadece evsât ve ednâ evraka sahiptirler. Evsât evrak sahipleri Dört Ayak, Dut Dibi, Kapu Bölüğü, Rikabiye, Sofilar ve Tabii Sofilar'da ikamet etmekte olup 38 kişiydiler. Defterdeki çürüklere rağmen bu mahallelerde yaşayan evrak sayısı 333 kişi olarak tespit edilmiştir. Oysaki 1842 tarihli tahrirde toplam 355 evsat evrak olduğu dikkate alındığında, çürük kısımda tespit edilemeyen sadece 22 cizye mükellefinin olduğunu söylemek mümkündür. Bu sonuçtan hareket edilirse söz konusu mahallerde 1842 ve 1843 'te hemen hemen aynı nüfusun olduğu ileri sürülebilir (bkz. Tablo 4).

Buna göre 1843 tarihinde Antakya'da bulunan toplam gayrimüslim hane sayısı meslekler üzerinden ele alındığında 1.525 hane olduğu söylenebilir. Bu haneler Ö. Lütfi Barkan'ın hane sayısı dikkate alındığında 1843 tarihinde Antakya ve bağı ınhiyelerde 7.625 kişi gayrimüslim yaşadığı düşünülmektedir. Bu durumda 1842 ile 1843 tarihli tahrirler arasında yaklaşık 1.010 kişi nüfus farkı bulunmaktadır ki, buna göre 1843 tarihinde görülen bu düşüşün, bir sene içinde herhangi bir nedenle nüfusta meydana gelmiş bir düşüşten değil, defterdeki çürüklerden tespit edilemeyen verilerden kaynaklandığını, buna mukabil en fazla 2030 civarında bir nüfus farklıı̆ı̆ın olduğunu söylemek yerinde olacaktır.

1844 Tarihli Tahrire Göre Antakya ve Tabii Nahiye ve Karyelerdeki Cizye Mükellefleri

\section{Tarihli Cizye Defterinin Durumu}

Başbakanlık Osmanlı Arşivi Cevdet Dâhiliye, nr. 186/9275'da kayıtlı defterin baş tarafında tahririn hangi tarihte yapıldığına ve hangi birimleri kapsadığına dair bir bilgi notunun olmadığı dikkat çekmektedir. Defterin icmâl kısmına 1844 tarihi düşülmüş olması, defterin bu tarihte tutulmuş olduğunu ve tahririn de bu tarihlerde yapılmış olduğu

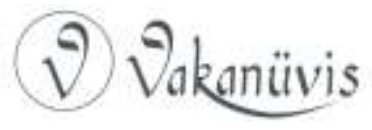


izlenimini vermektedir. Defter "Antakya", "Süveydiye", "Cebel-i Akra" ve "Nahiye-i Kuseyr", "Mürûr ü Ubûr Eden Garib" bölümleri ile "icmâl" olmak üzere toplam $31+1$ boş sayfadır. Defterin detayına bakıldığında Antakya bölümünde "Rum", "Yahudi" ve "Ermeni" taifeleri, Süveydiye bölümünde "Hacı Habiblü", "Yoğunoluk", "Kabusiye" ve "Zeytuniye" karyeleri, Cebel-i Akra'da ise "Keseb" ve "Ordu" karyeleri, Nahiye-i Kuseyr'de ise "Cünte" ve "Suriye" karyeleri yer almaktadır. İcmal olarak verilen son bölümde ise bütün bu yerleşim yerlerine ait verilerin toplamı hakkında bilgiler verilmiştir ${ }^{58}$.

Defterin son kısmında kısa bir icmâl ve defterin hangi maksatla düzenlendiğini izah eden 8 satırlık bir açıklama mevcuttur. Bu açılamada Muharrem 1260 senesinde yapılan tahrir sonucunda Antakya ve nahiyelerinde 17 adet a'lâ, 1.206 adet evsât ve 554 adet ednâ cizye evrak mükellefi bulunduğu ifade edilmektedir. Bu tahrirde merkezden gönderilen memur dışında bölgenin kocabaşısı da yer almıştır. Söz konusu tarihte Antakya'ya dışarıdan gelip gidenlerin tahriri de yapılmıştır. Tahrir sonrasında ayrıca 2 adet a'lâ ve 2 adet evsât cizye evrakı tespit edilmiştir. Tahrire tabi tutulan bütün vergi mükelleflerinden toplamda 45.330 kuruş tahsil edilmiş ve tayin edilen katibe de 500 kuruş verilmiştir. Kalan kısım ise Halep hazinesine gönderilmiştir. Bununla beraber tahsilatın tam olarak bitirilemediği anlaşılmaktadır. Yukarıda bahsi geçen 2 adet a'lâ ve 2 adet evsât cizye evrakı ise elden hazineye teslim edilmiştir ${ }^{59}$.

\section{Tarihli Cizye Tahririne Göre Kişi Başına Düşen Cizye Geliri}

Defterin düzenine bakıldığında 1842, 1843 tahrirlerinde olduğu gibi veriler kuruş cinsinden girilmiştir. Defterde yer alan mükelleflerin tamamı gayrimüslimdir. Tahsil edilen vergi "a'lâ", "evsât" ve "ednâ" olarak yazılmıştır. Defterde mükelleflerin kişisel özelliklerine de yer verilmiştir. Mükellefin adı, şöhreti, sanatı, oturduğu mahalle, yaşı, sakal, bıyık ve göz renkleri ve son olarak da hane numarası cetvellere işlenmiştir.

\footnotetext{
${ }^{58}$ BOA, Cevdet Dâhiliye, nr. 186/9275, Muharrem 1260/Ocak 1844.

59 Defterin sonunda 15 adet tasdik mührü bulunmaktadır (BOA, Cevdet Dâhiliye, nr. 186/9275, s. 31).
}

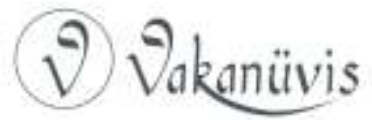


Antakya, her ne kadar mahallelere bölünmüş olsa da cemaatler Rum, Ermeni ve Yahudi olarak üç ayrı bölümde tahrire tabi tutulmuştur. Antakya Rum cemaatine ait vergi mükellefleri toplam 274 kişidir. Bunlardan 13'ü a'lâ (60 kuruş), 121'i evsât (30 kuruş) ve 140'ı ise ednâ (15 kuruş) olarak nitelendirilmiştir. Antakya Rum taifesinin söz konusu yıl devlete ödemiş olduğu toplam cizye bedeli 6.510 kuruş olarak kayıtlara geçmiştir ${ }^{60}$. Defterde yer alan Antakya Yahudilerine ait cizye evrakı toplam 2 adet a'lâ, 22 adet evsât ve 24 adet ednâ'dır. Bu evraktan devlete intikal eden vergi 1.140 kuruştur ${ }^{61}$. Antakya'daki Ermeniler ise 37 kişidir. Bunların 17'si evsât, 19'u ise ednâ'dır. Bu cizye evrakından hazineye intikal eden vergi miktarı ise 810 kuruştur (Bkz. Tablo 5$)^{62}$.

Tablo 5. 1844 Tarihinde Kişi Başına Düşen Cizye Evrak Bedeli

\begin{tabular}{|c|c|c|c|c|c|}
\hline & & & Cizye Evrakı & & \\
\hline Yerleşim Yerleri & Kişi & $\begin{array}{ll}\text { A'lâ } & 60 \\
\text { Krş. } & \\
\text { Adet } & \end{array}$ & $\begin{array}{ll}\text { Evsât } & 30 \\
\text { Krş. } & \\
\text { Adet } & \end{array}$ & $\begin{array}{ll}\text { Ednâ } \quad 15 \\
\text { Krş. } \\
\text { Adet }\end{array}$ & $\begin{array}{l}\text { Toplam } \\
\text { Krş. }\end{array}$ \\
\hline Antakya Rum Taifesi & 274 & 13 & 121 & 140 & 6510 \\
\hline Antakya Yahudi Taifesi & 48 & 2 & 22 & 24 & 1140 \\
\hline Antakya Ermeni Taifesi & 37 & & 18 & 19 & 810 \\
\hline $\begin{array}{l}\text { Süveydiye Nahiyesi Hacl } \\
\text { Habiblü Karyesi }\end{array}$ & 216 & & 167 & 49 & 5745 \\
\hline $\begin{array}{ll}\text { Süveydiye } & \text { Nahiyesi } \\
\text { Yoğunoluk Karyesi } & \end{array}$ & 306 & & 228 & 87 & 8145 \\
\hline Süveydiye Nahiyesi Kabusiye & 77 & & 57 & 20 & 2015 \\
\hline $\begin{array}{ll}\text { Süveydiye } & \text { Nahiyesi } \\
\text { Zeytuniye Karyesi } & \end{array}$ & 315 & & 216 & 99 & 7965 \\
\hline Cebel-i Akra Keseb Karyesi & 265 & & 205 & 60 & 7050 \\
\hline Cebel-i Akra Ordu Karyesi & 49 & & 37 & 12 & 1275 \\
\hline $\begin{array}{lll}\begin{array}{l}\text { Kuseyr } \\
\text { Karyesi }\end{array} & \text { Nahiyesi } & \text { Cünte } \\
\end{array}$ & 75 & & 59 & 15 & 1990 \\
\hline $\begin{array}{lll}\text { Kuseyr } & \text { Nahiyesi } & \text { Suriye } \\
\text { Karyesi } & & \\
\end{array}$ & 83 & & 69 & 14 & 2280 \\
\hline Mürûr ü Ubûr Eden & 20 & & 13 & 7 & 405 \\
\hline Toplam & 1765 & 15 & 1212 & 546 & 45330 \\
\hline
\end{tabular}

Süveydiye nahiyesi Hacı Habiblü karyesinde bulunan gayrimüslimler hakkında Rum, Ermeni veya Yahudi şeklinde herhangi bir etnik kimlik

60 BOA, Cevdet Dâhiliye, nr. 186/9275, s. 1-5.

61 BOA, Cevdet Dâhiliye, nr. 186/9275, s. 5-6.

62 BOA, Cevdet Dâhiliye, nr. 186/9275, s. 6-7. 
belirtilmemiştir. Hacı Habiblü karyesindeki cizyegüzârlar 216 kişidir. Bu mükellefler 167 evsât ve 49 ednâ evraka sahiptir. Bu evraktan hazineye intikal eden vergi miktarı 5.745 kuruştur $^{63}$. Süveydiye nahiyesine bağlı Yoğunoluk karyesinde bulunan gayrimüslim tebaa ise 306 kişidir. Bunlardan 228'i evsât ve 87 'si ise ednâ'dır. Yoğunoluk'taki cizye evrakından hazineye 8.145 kuruş intikal etmiştir ${ }^{64}$.

Süveydiye nahiyesi Kabusiye karyesinde ikamet eden 77 mükelleften 57'si evsât, 20'si ise ednâ sınıfa dâhildi. Bu mükelleflerden Halep hazinesine intikal eden vergi miktarı 2.015 kuruştur ${ }^{65}$. Yine aynı nahiyeye bağlı Zeytuniye karyesinde meskûn 315 vergi mükellefinden 216 'sı evsât, 99'u ednâ olup bu evraktan hazineye intikal eden vergi miktarı ise 7.965 kuruştur ${ }^{66}$.

Cebel-i Akra'ya tabi karyelerden Keseb'de 265 cizyedar bulunmaktadır. Bu mükelleflere ait cizye evrakının 205'i evsât ve 60'ı ednâ'dır. Bu mükelleflerden hazineye intikal eden vergi miktarı 7.050 kuruştur $^{67}$. Cebel-i Akra'ya bağı Ordu'da ise 49 vergi mükellefi vardı. Bunların 37'si evsât, 12'si ednâ sınıfa mensuptu. Bu iki sınıftan hazineye intikal eden vergi miktarı da 1.275 kuruştu $^{68}$.

Kuseyr nahiyesine ait iki ayrı karye tespit edilmiştir. Cünte karyesinde toplam 75 cizyedar vardı. Bu evrakın 59'u evsât, 15'i ednâ idi. Bu evraktan hazineye intikal eden meblağ ise 1.990 kuruştur $^{69}$. Kuseyr nahiyesine ait diğer karye Suriye olup, bu karyedeki vergi mükellefleri toplam 83 kişidir. Bunların 69'u evsât, 14'ü ednâ'dır. Bu evraktan hazineye intikal eden meblağ is 2.280 kuruştur $^{70}$.

1844 yılında Antakya'ya "mürûr ü ubûr eden/gelip ve geçen" gayrimüslimlerin toplamı 20 kişi olup bunlardan 13'ü evsât, 7'si ednâ evraklıdır. Bunlardan hazineye intikal eden vergi miktarı 405 kuruştur ${ }^{71}$.

\footnotetext{
${ }^{63}$ BOA, Cevdet Dâhiliye, nr. 186/9275, s. 7-11.

${ }^{64}$ BOA, Cevdet Dâhiliye, nr. 186/9275, s. 11-16.

65 BOA, Cevdet Dâhiliye, nr. 186/9275, s. 16-17.

66 BOA, Cevdet Dâhiliye, nr. 186/9275, s. 17-22.

67 BOA, Cevdet Dâhiliye, nr. 186/9275, s. 22-27.

68 BOA, Cevdet Dâhiliye, nr. 186/9275, s. 27-28.

${ }^{69}$ BOA, Cevdet Dâhiliye, nr. 186/9275, s. 28-30.

70 BOA, Cevdet Dâhiliye, nr. 186/9275, s. 30-31.

${ }^{71}$ BOA, Cevdet Dâhiliye, nr. 186/9275, s. 31.
} 
1844 tarihli bu nüfus ve cizye defterinden Halep hazinesine intikal eden vergi miktarı toplam 45.330 kuruştur. Bu tahririn yapılması için kâtibe ödenen miktar ise 500 kuruştur. Bu meblağ ile tahrire harcanan toplam bedel ise 45.830 kuruştur $^{72}$.

\section{Tarihli Cizye Tahririne Göre Meslek Sahipleri}

1844 tarihli nüfus ve cizye defterine göre Antakya'da 72 çeşit meslek dalına tesadüf edilmektedir. Bu meslek dallarının mahallelere göre dağılımına bakıldığında, Antakya'daki 274 Rum'dan 273'ü hakkında, 48 Yahudi'den 46 'sı hakkında ve 37 Ermeni'den ise 35'i hakkında bir meslekte çalıştığı kaydına tesadüf edilmektedir (bkz. Tablo 2).

Süveydiye Nahiyesi'ne bağlı Hacı Habiblü, Yoğunoluk, Kabusiye ve Zeytuniye karyelerinde bulunan meslek dalları hakkında da geniş malumat edinilebilmektedir. Bu karyelerden 216 vergi mükellefine sahip olan Hacı Habiblü karyesinde 214 vergi mükellefinin bir mesleğe dâhil olduğu belirtilmiştir. 306 vergi mükellefinin ikamet ettiği Yoğunoluk karyesinin tamamı bir meslek sahibi olduğu anlaşılmaktadır. 77 kişi mükellefe sahip Kabusiye karyesinde bulunan mükelleflerden 76'sı bir meslek sahibi idi. Süveydiye nahiyesine bağlı 315 mükellefin bulunduğu Zeytuniye karyesindeki nüfusun ise 311 ' $i$ bir meslek sahibi idi (bkz. Tablo 2).

Tablo 6. 1844 Tarihli Cizye Defterine Göre Meslekler (Kişi/Kişi)

\begin{tabular}{|c|c|c|c|c|c|c|c|c|c|c|c|c|c|}
\hline 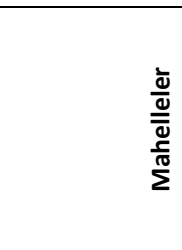 & 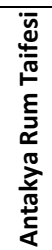 & 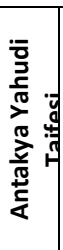 & 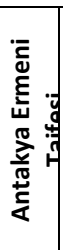 & 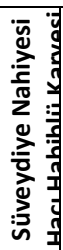 & 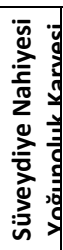 & 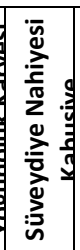 & 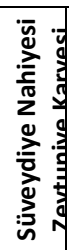 & 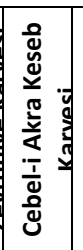 & 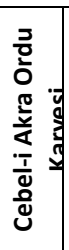 & 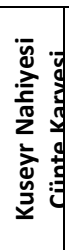 & 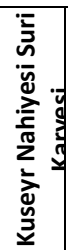 & 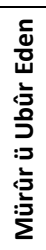 & $\begin{array}{l}\sum \\
\vdots \\
0 \\
0\end{array}$ \\
\hline Abacl & 28 & & 2 & 2 & & & & & 2 & 1 & & & 34 \\
\hline Abid & 1 & & & & & & & & & & & & 2 \\
\hline Aciz & & & & & & & 1 & & & & 3 & & 4 \\
\hline Attar & 9 & 16 & & & & & & & & & & & 25 \\
\hline Avatlı & 1 & & & 8 & 1 & 1 & & 2 & & & 1 & & 14 \\
\hline Bakkal & 4 & & & & & & & & & & & & 4 \\
\hline Basmacl & & & 3 & & & & & & & & & & 3 \\
\hline Baytar & 5 & & & & & & & & & & & & 5 \\
\hline Bazergan & 24 & 17 & & & & & & & & & & & 41 \\
\hline Berber & & & & & & & 2 & & $1 \mid$ & 1 & & & 4 \\
\hline
\end{tabular}

72 BOA, Cevdet Dâhiliye, nr. 186/9275, s. 31. 


\begin{tabular}{|c|c|c|c|c|c|c|c|c|c|c|c|c|c|}
\hline Boyacı & 4 & & 1 & 2 & & & & & 1 & & & & 8 \\
\hline Canbaz & & & & & 1 & & & & & & & & 1 \\
\hline Cebelü & & & & 1 & & & & & & & & & 1 \\
\hline Cakıcı & & & & & 1 & & 1 & & & & & & 2 \\
\hline Cerçi & 5 & 10 & 1 & 1 & 2 & & 3 & & & & & 3 & 25 \\
\hline Ciftçi & & & & 1 & 6 & & 1 & & & 28 & & & 36 \\
\hline Coban & & & & & & & 1 & & & 1 & & & 2 \\
\hline Culfacl & & & 2 & & 1 & & 1 & 1 & & & & & 5 \\
\hline Düdükcü & & & & 1 & & & & & & & & & 1 \\
\hline Eskici & 1 & & & & & & & & & & & & 1 \\
\hline Fail & 12 & & 6 & 195 & 290 & 74 & 294 & 259 & 1 & 34 & 20 & 7 & 1192 \\
\hline Fașal & & & & & 1 & & & & & & & & 1 \\
\hline Gemici & & & & & & & & & & & & 5 & 5 \\
\hline Halife & & & & & & & & & & 2 & 5 & & 7 \\
\hline Hallac & & & 1 & & & & & & 1 & 2 & & & 4 \\
\hline Hattab & & & & & & & & & 1 & & & & 1 \\
\hline Hayik & 2 & & & & & & & & & & 47 & & 49 \\
\hline Havvat & & & & & & 1 & 1 & & & & 1 & & 3 \\
\hline Kahya & & & & 1 & & & 2 & & & 1 & 1 & & 5 \\
\hline Kalavcı & 8 & & 4 & & & & & & & & & & 12 \\
\hline Kantara & 1 & & & & & & & & & & & & 1 \\
\hline Kapıcı & 1 & & & & & & & & & & & & 1 \\
\hline Kasap & 1 & & & & & & & & & & & & 1 \\
\hline Kastal & 1 & & & & & & & & & & & & 1 \\
\hline Katırcl & & & & 1 & & & & & & & & & 1 \\
\hline Kattan & 1 & & 1 & & & & & & & & & & 2 \\
\hline Katip & 1 & & & & 1 & & & & & 1 & & & 3 \\
\hline Kazancı & 15 & & & & & & & & & & & & 15 \\
\hline Kesker ${ }^{73}$ & 1 & & & & & & & 2 & 23 & & & & 26 \\
\hline Kılınccl & 1 & & 1 & 1 & & & & & 6 & & & 1 & 10 \\
\hline Kınacı & 1 & & & & & & & & & & & 2 & 3 \\
\hline Kızılçin & & & & & 1 & & & & & & & & 1 \\
\hline Kuyumcu & 10 & & 9 & & & & & & & & & & 19 \\
\hline Kürkcü & 2 & & & & & & & & & & & & 2 \\
\hline Mevhaneci & 1 & & & & & & & & & & & & 1 \\
\hline Mikyas & & & & & & & 1 & & & & & & 1 \\
\hline Mimar & 58 & & & & & & & & 1 & 1 & 1 & & 61 \\
\hline Mübevviz & 2 & & 1 & & & & & & & & & & 3 \\
\hline Münir & 2 & & & & & & & & & & & & 2 \\
\hline Naalband & 3 & & & & & & & & & & & & 3 \\
\hline Nail & & & & & & & & & & 1 & & & 1 \\
\hline Tüccar & 8 & 2 & & & & & & & & & & & 10 \\
\hline Odabaşı & & & 3 & & & & & & & & & & 2 \\
\hline $\mathrm{Rai}^{74}$ & & & & & & & & & & & 1 & & 1 \\
\hline Sarraf & 1 & & & & & & & & & & & & 1 \\
\hline Semerci & 14 & & & & & & & & 2 & & & & 16 \\
\hline Sevak & & & & & 1 & & & & & 1 & 2 & & 4 \\
\hline SivacI & & & & & & & 1 & & & & & & 1 \\
\hline Sibağ & & & & & & & 2 & 1 & 2 & & & & 5 \\
\hline Simsar & 2 & & & & & & & & & & & & 2 \\
\hline Tarablik-i bahri & & & & & & & & & & & 1 & & 1 \\
\hline Tarakcı & 1 & & & & & & & & & & & & 1 \\
\hline Terzi & 36 & & & & & & & & & & & & 36 \\
\hline Teymürci ${ }^{75}$ & & 1 & & & & & & & & & & & 1 \\
\hline
\end{tabular}

${ }^{73}$ Keşker/Köşger: Ayakkabı imalatçısı.

${ }^{74}$ Ra'i: Çoban, gözetleyici.

75 Teymürci: Demirci. 


\begin{tabular}{|l|r|r|r|r|r|r|r|r|r|r|r|r|l|}
\hline Tütüncü & 5 & & & & & & & & & & & & 5 \\
\hline Yazıcı & & & & & & & & & & 1 & & & 1 \\
\hline & & & & & & & & & & & & & \\
Toplam & $\mathbf{2 7 3}$ & $\mathbf{4 6}$ & $\mathbf{3 5}$ & $\mathbf{2 1 4}$ & $\mathbf{3 0 6}$ & $\mathbf{7 6}$ & $\mathbf{3 1 1}$ & $\mathbf{2 6 5}$ & $\mathbf{4 1}$ & $\mathbf{7 5}$ & $\mathbf{8 4}$ & $\mathbf{1 8}$ & $\mathbf{1 7 4 3}$ \\
\hline
\end{tabular}

Tablo 6'dan da görüleceği üzere 1844 yılında Antakya ve bağlı beldelerde toplam 72 çeşit meslek bulunmaktadır. Bu mesleklerin dağılımına bakıldığında Cebel-i Akra'ya bağlı Keseb ve Ordu karyelerinden 265 mükellefin olduğu Keseb'de nüfusun tamamının bir meslek edinmiş olduğu tespit edilebilmektedir. Aynı şekilde 49 mükellefin olduğu Ordu karyesinde de 41 kişinin bir meslek sahibi olduğu anlaşılmaktadır (bkz. Tablo 6).

Kuseyr Nahiyesi'ne bağlı Cünte ve Suri(ye) karyelerinden 75 kişinin olduğu Cünte karyesindeki mükelleflerin tamamı bir mesleğe tabiyken, 83 mükellefin ikamet ettiği Suriye karyesindeki mükelleflerden her birinin bir meslek sahibi olduğu tespit edilebilmektedir(bkz. Tablo 6).

Son olarak Antakya ve çevresinde ikamet etmemekle beraber geçici olarak şehirde bulunan "mürûr ve ubûr edenler/yani gelip geçen yaklaşık 20 kişi bulunmaktaydı. Bunlardan 18 'inin bir meslek sahibi olduğu ifade edilmiştir(bkz. Tablo 6).

Bütün bu kayıtlar esas alındığında Antakya ve çevresinde bulunan ve 1844 yılında sayıma tabi tutulan Antakya ve diğer üç nahiyedeki toplam gayrimüslim nüfus 1.765 kişi olarak tespit edilmiştir. Bunlardan 1.743'ü Tablo 6' da belirtilen 72 meslekten en az bir tanesinde faaldi.

\section{Tarihli Cizye Tahririne Göre Vergi Mükellefleri}

1844 tarihinde gerçekleştirilen cizye tahririnde Antakya'nın toplam 16 mahallesinde yaşayan gayrimüslim vergi mükellefleri hakkında bilgi verilmiştir. Bu mahallelerden Cünte'de 69 Rum, Dört Ayak'ta 13 Ermeni, Dut Dibi'nde 8 Yahudi ve 6 Ermeni vergi mükellefi bulunmaktaydı. Günlük denilen mahallede 7 Rum ve 5 Yahudi'nin vergi mükellefi olduğu tespit edilebilmektedir. Han mahallesinde ise sadece 1 Yahudi esnaf vardı. Kantara mahallesinde 22 Rum ve 19 Yahudi, Kastal'da 53 Rum, Koca Abdi'de 10 Yahudi, Lakbise'de 1 Ermeni, Mahsen'de 36 Rum, 3 Yahudi ve Mukbil'de ise sadece 3 Rum vergi mükellefi vardı. Rikabiye mahallesinde ise 1 Ermeni vergi mükellefi bulunmakta olup, Saha mahallesinde de 1 Ermeni vergi mükellefine rastlanılmıştır. Vergi mükellefleri açısından en kalabalık mahalle 75 mükellef ile Sarı Mahmud

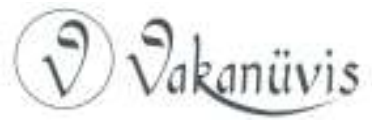


mahallesiydi. Sofilar mahallesinde sadece 14 Ermeni mükellef varken, Şenbek mahallesinde 7 Rum ve 1 Ermeni bulunmaktaydı (bkz. Tablo 8).

1844 nüfus ve cizye defterinde yer alan Süveydiye, Cebel-i Akra ve Kuseyr nahiyelerindeki gayrimüslimlere ait veriler incelendiğinde Süveydiye $\mathrm{Hacı}$ Habiblü karyesinde 216, Yoğunoluk karyesinde 315, Kabusiye karyesinde 77 ve Zeytuniye karyesinde ise 315 vergi mükellefi tespit edilmiştir. Cebel-i Akra Keseb karyesinde 265, Ordu karyesinde ise 61; Kuseyr nahiyesi Cünte karyesinde 74, Suri karyesinde ise 83 vergi mükellefi tespit edilmiştir. 1844 yılında Antakya'nın mahallelerine ve söz konusu nahiyelere gelen ve giden gayrimüslimler 20 kişi idi. Sayım sonucunda bütün bu birimlerde bulunan vergi mükellefi sayısı toplam 1.781 kişi olarak tespit edilmiştir (bkz. Tablo 8).

Tablo 8. 1844 Cizye Defterine Göre Antakya Mahallelerindeki Vergi Mükellefleri

\begin{tabular}{|l|l|l|l|l|}
\hline Mahalle & $\begin{array}{l}\text { Rum } \\
\text { Kişi }\end{array}$ & $\begin{array}{l}\text { Yahudi } \\
\text { Kişi }\end{array}$ & $\begin{array}{l}\text { Ermeni } \\
\text { Kişi }\end{array}$ & TOPLAM \\
\hline Cünevne (Cünte) (Cünte) & 69 & & & 69 \\
\hline Dört Avak & & & 13 & 13 \\
\hline Dut Dibi & & 8 & 6 & 14 \\
\hline Günlük & 7 & 5 & & 12 \\
\hline Han & & 1 & & 1 \\
\hline Kantara & 22 & 19 & & 41 \\
\hline Kastal & 53 & & & 53 \\
\hline Koca Abdi & & 10 & & 10 \\
\hline Lakbise & & & 1 & 1 \\
\hline Mahsen & 36 & 3 & & 39 \\
\hline Mukbil & 3 & & & 3 \\
\hline Rikabive & & & 1 & 1 \\
\hline Saha & & & 1 & 1 \\
\hline Sarı Mahmud & 75 & & & 75 \\
\hline Sofilar & & & 14 & 14 \\
\hline Senbek & 7 & 1 & & 8 \\
\hline Toplam & $\mathbf{2 7 2}$ & $\mathbf{4 7}$ & $\mathbf{3 6}$ & $\mathbf{3 5 5}$ \\
\hline
\end{tabular}

1844 tarihli cizye tahririne göre Antakya ve nahiyelerinde toplam 1.781 cizye mükellefinin bulunduğu tespit edilebilmektedir. Bu mükelleflerin her biri bir hane olarak düşünüldüğünde her hane 5 kişi

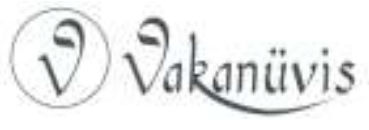


farz edilirse, Antakya ve nahiyelerinde toplam 8.905 gayrimüslimin olduğu söylenebilir. Bu durumda 1842'den 1844 yılına kadar söz konusu yerlerde gayrimüslim nüfusun yaklaşık 270 kişi kadar artmış olduğunu söylemek mümkündür.

\section{Tarihli Cizye Tahririne Göre Antakya ve Çevresinde Nüfus ve Yerleşim}

\section{Defterin Durumu}

Başbakanlık Osmanlı Arşivi Maliye Nezareti Varidat Muhasebesi tasnifinde bulunan cizye defterleri arasına kaydedilmiş olan bu defter (ML.VRD.CMH.d, nr. 573) kırk dört sayfadır. Defterin ilk sayfası "Antakya" başlığına ayrılmış olup, ikinci sayfada her defterde olması gereken ve defterin ne amaçla tutulduğunu gösteren başlık kısmı mevcuttur. Bu kısımda "1262 senesi Muharremi'ne mahsuben Antakya Kazası'nda kâffe-i re'âyânın cizye defteridir. Ber-vech-i ati beyân olunur." ibaresi yer almaktadır. Defter bu aşamadan sonra daha önceki defterlerde olan düzen içerisinde devam etmektedir. Defterin veri akışı "icmâl", a'lâ, evsât, ednâ, nâm, veled, şöhret, sanat, mahalle, sin, boy, sakal, bıyık, göz ve numara şeklindedir.

Defter, diğer defterlerde olduğu gibi önce Antakya mahallelerinde meskûn olan taife-i Rum ile başlasa da farklı olarak her cizye kalemi ayrı bir kategoride (Örneğin: Rum taifesi, a'lâ, esât ve ednâ başlıkları altında ayrı yerlerde) verilerek, farklı bir kayıt sistemi oluşturulmuştur.

Buna mukabil önceki defterlerde bütün cizye kalemleri alt alta aynı düzenin devamı şeklinde verilirken, bu tahrirde yeni bir düzen tercih edilmiştir.

Defterin ilk dokuz sayfası bu şekilde düzenlenirken, dokuz ve onuncu sayfalar Antakya mahallelerinde bulunan "Taife-i Yahudi"ye yer verilmiştir. On birinci ve on ikinci sayfalar "Taife-i Ermeniyân"a tahsis edilmiştir. On üçüncü sayfada Antakya'ya gelip-giden "gurebâ ve reâya" tahrir edilmiştir. Aynı sayfanın sonundan on beşinci sayfaya kadar Suriye karyesindeki evsât haneler ve on beşinci sayfada ednâ haneler kayıtlıdır. On altıncı ve on yedinci sayfa sonuna kadar Antakya'ya tabi olan Cünte karyesine ait veriler bulunur. On sekizinci sayfada Antakya'ya tabi olan Ordu karyesindeki taife-i Rum; on dokuzuncu ve yirmi beşinci sayfalarda taife-i Ermeniyân'ın meskûn olduğu Antakya'ya tabi Keseb karyesi

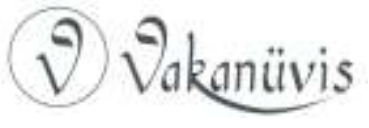


kaydedilmiştir. Aynı düzen içerisinde yirmi beşinci sayfadan başlatılarak otuz birinci sayfaya kadar Antakya'nın Zeytuniye karyesindeki Rum ahaliye ait veriler sıralanır. Otuz ikinci ve otuz üçüncü sayfalar arasında Antakya'ya tabi Kabusiye karyesinde bulunan Ermenilere; otuz üçüncü ve kırkıncı sayfalar arası ise Antakya'ya tabi Yoğunoluk karyesine ait Ermeni taifesine ayrılmıştır. Defterin kırkıncı sayfasından kırk üçüncü sayfasına kadar ise Hacı Habiblü karyesindeki Ermenilerin cizye evrakı kayıtlıdır.

1846 tarihli bu defterin sonunda detayı olmayan bir icmâl verilerek a'lâ, evsât ve ednâ cizye evrakı miktarları belirtilir. Bu açıklamanın altında ise toplam cizye bedeli ve kâtibe ödenen meblağ yer almaktadır. Defterin kırk dördüncü sayfasında yer alan bu bilgilerin sonunda yapılan açıklamada; 1262 senesi Muharremi'nin başlangııından, sonuna kadar Antakya'nın merkezinde ve köylerinde oturan reaya ile gelip geçen garip ve gurebanın tabi oldukları cizye evrakının 16 adet a'lâ, 1.135 adet evsât ve 728 adet ednâ oldukları belirtilmektedir. Bu evrakın tahririnde kocabaşının yanı sıra merkezden gönderilen bir memur da yer almıştır. Toplam tahsil edilen bedel 45.930 kuruşu bulmuştur. Cizye memuru ve katibine beş yüz kuruş yevmiye verilmek üzere Halep hazinesine toplam kırk beş bin dört yüz otuz kuruş teslim edilmiştir (27 Zilkade 1262) ${ }^{76}$. Defterin hemen sonunda 14 adet imza/mühür yer almaktadır ${ }^{77}$.

Burada dikkat çeken husus 1844 tahririnde Süveydiye, Cebel-i Akra ve Kuseyr nahiyelerine bağlı olan köylerin tamamının 1846 tarihinde Antakya kazasına tabi kılınmış olmasıdır. Adem Kara tarafından yayınlanmış olan 1258/1842 tarihli (ML.CMH, nr. 138, s. 1-31) defter ile 1844 tarihli defter aynı kayıt düzenine sahiptir ${ }^{78}$.

\section{Kişi Başına Düşen Cizye Evrakı}

Tablo 9'da da görüleceği üzere 1846 tahririnde Antakya, Süveydiye, Cebel-i Akra ve Kuseyr nahiyelerinde toplam cizyegüzâr sayısı 1.683 olarak verilmiştir. Bütün bu vergi mükelleflerinden elde edilen cizye geliri 45.840 kuruştur. Tahrir bitmiş olmasına rağmen sonradan 1 adet a'lâ ve 1 adet evsât cizye evrakının elden hazineye teslim edildiği kaydedilmiştir. Bu meblağ ile toplam vergi geliri 45.930 kuruş olmuştur.

\footnotetext{
76 BOA, ML.VRD.CMH.d, nr. 573, s.44.

77 BOA, ML.VRD.CMH.d, nr. 573, s. 44.

78 Kara, "XIX. Yüzyılın İlk Yarısında Antakya'da Yerleşme ve Nüfus", s. 1-14.
}

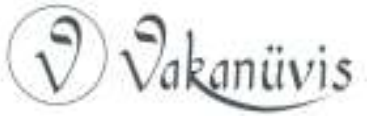


Ancak bu meblağın 500 kuruşu tahriri kaydeden katibe verilmiş olduğundan Halep hazinesine gönderilen vergi miktarı sadece 45.430 kuruş olmuştur (bkz. Tablo 9).

1846 tahririnde Rum, Yahudi ve Ermeniler hem mahalle ve hem de karye olarak gösterilmiştir. Oysaki önceki tahrirlerde sadece Antakya mahallelerine ait cemaatler ismen açıkça belirtilmişti. Bu tahrirde ise bütün yerleşim birimlerindeki cemaatlere ait isimler verilerek tahririn yapıldığı görülmektedir. Buna göre nefs-i Antakya'da yani Antakya'nın merkezinde Rum, Yahudi ve Ermeni olarak 389 kişi kaydedilmiş ve bunlardan toplam 8.820 kuruş cizye tahsil edilmiştir. Hacı Habiblü karyesindeki 204 Ermeni'den tahsil edilen cizye miktarı 5.310 kuruştur. Yoğunoluk karyesindeki 327 Ermeni'den alınan toplam vergi ise 8.250 kuruş idi. Kabusiye karyesinde ise 72 Ermeni vardı ve bunlardan alınan vergi ise 1.830 kuruş idi. Zeytuniye karyesindeki 312 Rum'dan ise 7.710 kuruş vergi tahsil edilmiştir. Keseb karyesinde ikamet eden 292 Ermeni vergi mükellefinin ödediği vergi miktarı ise 7.365 kuruştur.

Ordu karyesinde yaşayan 40 Rum'dan 930 kuruş; Cünte karyesindeki 78 Rum'dan 1.935 kuruş; Suriye karyesindeki 96 Rum'dan ise 2415 kuruş cizye alınmıştır. Bu durumda 1846 tahririnde bir mahalle ve dört karyede ikamet eden 836 Rum'un hazineye ödediği toplam cizye vergisi 20.085 kuruştur. Antakya ve çevresinde Yahudiler sadece şehir merkezinde ikamet etmekteydiler. 38 kişiden oluşan Yahudilerin hazineye gönderdiği cizye miktarı ise 780 kuruştur. Ermeniler ise bir mahalle ve dört karyede toplam 939 kişi kaydedilmiştir. Bu mükelleflerin hazineye göndermiş olduğu vergi miktarı ise 23.700 kuruş olmuştur(bkz. Tablo 9).

Tablo 9. 1846 Tarihli Tahrire Göre Kişi Başına Düşen Cizye Evrak Bedeli

\begin{tabular}{|l|l|l|l|l|l|l|l|l|}
\hline $\begin{array}{l}\text { Yerleşim } \\
\text { Yerleri }\end{array}$ & Kişi Sayısı & $\begin{array}{l}\text { A'lâ } \\
\text { Adet }\end{array}$ & $\begin{array}{l}\mathbf{6 0} \\
\text { Krş. }\end{array}$ & $\begin{array}{l}\text { Evsât } \\
\text { Adet }\end{array}$ & $\mathbf{3 0}$ Krş. & $\begin{array}{l}\text { Ednâ } \\
\text { Adet }\end{array}$ & $\mathbf{1 5}$ Krş. & $\begin{array}{l}\text { Toplam } \\
\text { Krş. }\end{array}$ \\
\hline $\begin{array}{l}\text { Antakya } \\
\text { Rum } \\
\text { Taifesi }\end{array}$ & 307 & 14 & 840 & 124 & 3720 & 169 & 2535 & 7.095 \\
\hline $\begin{array}{l}\text { Antakya } \\
\text { Yahudi } \\
\text { Taifesi }\end{array}$ & 38 & & & 14 & 420 & 24 & 360 & 780 \\
\hline
\end{tabular}

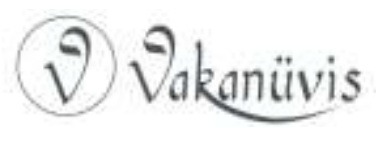




\begin{tabular}{|c|c|c|c|c|c|c|c|c|}
\hline $\begin{array}{l}\text { Antakya } \\
\text { Ermeni } \\
\text { Taifesi }\end{array}$ & 44 & & & 19 & 570 & 25 & 375 & 945 \\
\hline $\begin{array}{l}\text { Hacı } \\
\text { Habiblü } \\
\text { Karyesi } \\
\text { Taife-i } \\
\text { Ermeni }\end{array}$ & Verilmemiş & & & 150 & 4500 & 54 & 810 & 5.310 \\
\hline $\begin{array}{l}\text { Yoğunoluk } \\
\text { Karyesi } \\
\text { Taife-i } \\
\text { Ermeni }\end{array}$ & 327 & & & 223 & 6690 & 104 & 1560 & 8.250 \\
\hline $\begin{array}{l}\text { Kabusiye } \\
\text { Karyesi } \\
\text { Taife-i } \\
\text { Ermeni }\end{array}$ & 72 & & & 50 & 1500 & 22 & 330 & 1.830 \\
\hline $\begin{array}{l}\text { Zeytuniye } \\
\text { Karyesi } \\
\text { Taife-i } \\
\text { Rum }\end{array}$ & 312 & & & 202 & 6060 & 110 & 1650 & 7.710 \\
\hline $\begin{array}{l}\text { Keseb } \\
\text { Karyesi } \\
\text { Taife-i } \\
\text { Ermeni }\end{array}$ & 292 & & & 199 & 5970 & 93 & 1395 & 7.365 \\
\hline $\begin{array}{l}\text { Ordu } \\
\text { Karyesi } \\
\text { Taife-i } \\
\text { Rum }\end{array}$ & 40 & & & 22 & 660 & 18 & 270 & 930 \\
\hline $\begin{array}{l}\text { Cünte } \\
\text { Karyesi } \\
\text { Taife-i } \\
\text { Rum } \\
\end{array}$ & 78 & & & 51 & 1530 & 27 & 405 & 1.935 \\
\hline $\begin{array}{l}\text { Suriye } \\
\text { Karyesi } \\
\text { Taife-i } \\
\text { Rum }\end{array}$ & 96 & & & 65 & 1950 & 31 & 465 & 2.415 \\
\hline $\begin{array}{l}\text { Mürûr ü } \\
\text { Ubûr Eden }\end{array}$ & 67 & 1 & 60 & 15 & 450 & 51 & 765 & 1.275 \\
\hline Toplam & 1.683 & 15 & 900 & 1.134 & 34.020 & 728 & 10.920 & 45.840 \\
\hline $\begin{array}{l}\text { Defter } \\
\text { Toplamı: } \\
45.930 \\
500 \text { Katibe } \\
\text { verilen } \\
\text { Kalan: } \\
45.430\end{array}$ & & $\begin{array}{l}15+1 \\
\text { Noksan }\end{array}$ & 960 & $1134+1$ & 34.050 & 728 & 10.920 & 45.430 \\
\hline
\end{tabular}

1846 tahriri meslekler açısından incelendiğinde ortaya şöyle bir tablo çıkmaktadır:

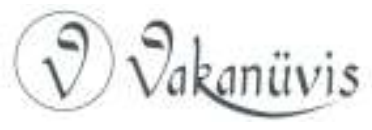


Tahrir sistemi içerisinde yerleşim yerlerinde 67 çeşit meslek sahibinin olduğu tespit edilebilmektedir. Bu tespit yapılırken defterin çürümüş olan kısımlarından kaynaklanan eksikliklerin olduğunu da unutmamak gerekmektedir. Defterden tespiti yapılabilen yerlerde toplamda 1.809 kişinin varlığı ve bunların her birinin en az bir mesleği ifa ettiği tespit edilebilmektedir.

Yerleşim yerleri dikkate alınarak ifade etmek gerekirse; Antakya merkezinde Rum (283 kişi), Yahudi (38 kişi) ve Ermeniler (43 kişi) olmak üzere toplamda 364 meslek erbâbı yaşamaktaydı. Bu meslek erbâbı arasında çoğunluğu abacı esnafı (51 kişi), mimarlar (49 kişi), kazzaz (21 kişi), terziler (20 kişi) ve fail yani her hangi bir işte çalışanlar (19 kişi) oluşturmaktaydı. Diğer meslek erbâbı ise attar (11 kişi), baytar (10 kişi), çerçi (12 kişi), kalaycı (14 kişi), neccar (10 kişi) ve semerci (15 kişi) şeklinde dağılım göstermekteydi. Bunların dışında başka meslek erbâbı olduğu da söylenebilir (bkz. Tablo 10).

Şehirde fazla bir yekûn tutmayan Yahudi taifesi arasında attar esnafı (15 kişi) en yoğun meslek olup bu meslek erbâbını 11 kişi ile çerci ve neccar sınıfı takip etmekteydi. Ermeniler arasında ise 12 kişi ile kuyumculuğun yaygın bir meslek olduğu gözlenmiştir(bkz. Tablo 10).

Karyelerdeki meslek erbâbı arasında Ermenilerin oldukça faal oldukları gözlenmektedir. Sadece Ermeni nüfusun yaşamakta olduğu Hacı Habiblü (204 kişi), Yoğunoluk (326 kişi), Kabusiye (72 kişi) ve Keseb (309 kişi) karyelerindeki nüfusun hemen tamamı bir işle meşgul idi. Bu nüfusun dahil olduğu meslek dalları arasında en yaygını her hangi bir işte çalışan "fail" grubudur (bkz. Tablo 9-10). Rum taifesinin yerleşik olduğu karyeler arasında Zeytuniye (309 kişi), Ordu (38 kişi), Cünte (78 kişi) ve Suriye (95 kişi) bulunmakta olup, bu karyelerde toplam 530 kişi tahrir edilmiştir. Rum taifesi içerisinde de en yoğun meslek erbâbını fail sınıfının oluşturmaktaydı (bkz. Tablo 9-10). Bölgeye gelip giden (mürûr ve ubûr) sınıfın (68 kişi) içerisinde ise yoğun olarak çerçilerin bulunduğunu söyleyebiliriz (bkz. Tablo 9-10). 
Tablo 10. 1846 Tarihli Tahrire Göre Meslekler

\begin{tabular}{|c|c|c|c|c|c|c|c|c|c|c|c|c|c|}
\hline$\frac{\frac{d}{d}}{\frac{\bar{d}}{\frac{c}{\pi}}}$ & 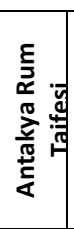 & 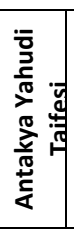 & 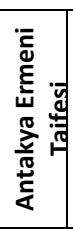 & 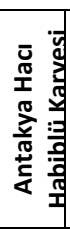 & 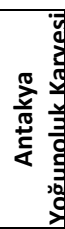 & 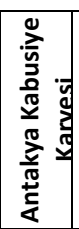 & 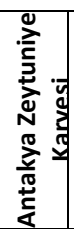 & 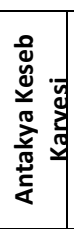 & 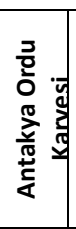 & 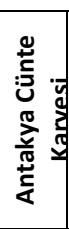 & 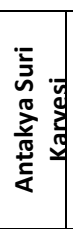 & 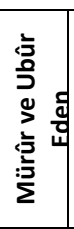 & $\begin{array}{l}\sum_{S} \\
\text { 은 }\end{array}$ \\
\hline Abacl & 51 & & & & & & 3 & & 3 & & & & 57 \\
\hline Aciz & & & & 1 & 3 & & 5 & 7 & 5 & 2 & 1 & & 24 \\
\hline Attar & 11 & 15 & & & & & & & & & & & 26 \\
\hline Avatlı & & & & & & 2 & 2 & & & & & & 4 \\
\hline Bahri & & & & & & & & & & & & 5 & 5 \\
\hline Bakkal & 3 & & & & & & & & & & & & 3 \\
\hline Balcı & & & & & & & & & & & & 2 & 2 \\
\hline Balıkçı & & & & & & & & & & & & 1 & 1 \\
\hline Basmacı & & & 5 & 1 & & & & & & & & & 6 \\
\hline Baytar & 10 & & & & & & & & & & & 2 & 12 \\
\hline Bazergan & 4 & & & & & & & & & & & & 4 \\
\hline Bederli & & & & & & & & 1 & & & & & 1 \\
\hline Berber & & & 1 & & & & 1 & & 1 & & 1 & 1 & 5 \\
\hline Bıçakçı & 1 & & & & & & & & & & & & 1 \\
\hline Boyacı & 3 & & & & & & & & 2 & & & 3 & 8 \\
\hline Çerçi & 12 & 11 & & 2 & & & 5 & 1 & & 6 & & 29 & 66 \\
\hline Çercis & 1 & & & & & & & & & & & & 1 \\
\hline Çiftçi & & & & & & 3 & 9 & & 2 & 23 & 4 & & 41 \\
\hline Çoban & & & & & & 1 & & 1 & & 3 & & & 5 \\
\hline Çulfacı & 1 & & 1 & 7 & 1 & & 13 & 10 & & 7 & 52 & & 92 \\
\hline Değirmenci & & & & & & & & 2 & & & & & 2 \\
\hline Eskici & 1 & & & & & & 1 & & & & 3 & & 5 \\
\hline Fail & 19 & & 6 & 186 & 316 & 66 & 253 & 211 & 2 & 28 & 2 & 5 & 1.094 \\
\hline Gemici & & & & & & & & & & & & 1 & 1 \\
\hline Hallaç & & & & & 1 & & 2 & & 1 & 1 & 1 & & 6 \\
\hline Hamal & & & 1 & & & & & & & & & 1 & 2 \\
\hline Hancl & & & 2 & & & & & & & & & & 2 \\
\hline Hattab & & & & & & & & & 1 & & & & 1 \\
\hline Hayik & 1 & & & 1 & & & & & & & 24 & & 26 \\
\hline Havvat & & & & & & & & 1 & & 1 & 1 & & 3 \\
\hline Huddam & 6 & 1 & & & & & 1 & 1 & & & & 2 & 11 \\
\hline İcir & & & & & & & & & & & & 1 & 1 \\
\hline İhtiyar & & & & 1 & & & & & & & & & 1 \\
\hline İneci & & 1 & & & & & & & & & & & 1 \\
\hline Kahveci & & & 2 & & & & & & & & & 1 & 3 \\
\hline Kalaycı & 14 & & 1 & & & & 2 & 1 & 4 & & & & 22 \\
\hline Kasar & & & 1 & & & & & & & & & & 1 \\
\hline Kattan & 1 & & & & & & & & & & & & 1 \\
\hline Katip & 1 & & & 1 & & & & & & 1 & & & 3 \\
\hline Kayıkçı & & & & 1 & & & & & & & & 1 & 2 \\
\hline Kazancı & 2 & & 2 & & 1 & & & 1 & & & & & 6 \\
\hline
\end{tabular}




\begin{tabular}{|c|c|c|c|c|c|c|c|c|c|c|c|c|c|}
\hline Kazzaz & 21 & & & & & & & & & & & & 21 \\
\hline Köşker & & & & & & & 5 & 10 & 14 & & 1 & & 30 \\
\hline Kılınççı & & & 8 & & & & & & & & & & 8 \\
\hline Köhne & & & & & & & & & & 1 & 1 & & 2 \\
\hline Kuyumcu & 8 & & 12 & & & & & & & & & 1 & 21 \\
\hline Kürkçü & 2 & & & & & & & & & & & & 2 \\
\hline Mekkareci & & & & & & & & & & 1 & & 2 & 3 \\
\hline Merbi & & & 1 & 1 & & & & & & & & & 2 \\
\hline Mellah & 1 & & & & & & & & & & & & 1 \\
\hline Mimar & 49 & & & & & & 3 & & & 1 & 2 & & 55 \\
\hline Mübeyyiz & 2 & & & & & & & & & & & & 2 \\
\hline Naalband & 1 & & & & & & & & & & & & 1 \\
\hline Neccar & 10 & 11 & & & & & & & & & & 6 & 27 \\
\hline Rencber & & & & & 2 & & & & & & & & 2 \\
\hline Saatçi & & & & & & & & & & & & 1 & 1 \\
\hline Semerci & 15 & & & & & & & & 2 & & & & 17 \\
\hline Sevak & & & & & & & & 7 & & 1 & 2 & & 10 \\
\hline Sibağ & 1 & & & 2 & 1 & & 2 & 1 & & & & 2 & 9 \\
\hline Simsar & 5 & & & & & & 1 & & & & & & 6 \\
\hline Solak & & & & & & & & & 1 & 1 & & & 3 \\
\hline Tahhan & & & & & & & & & & 1 & & & 1 \\
\hline Tarakçı & 2 & & & & & & & & & & & & 2 \\
\hline Terzi & 20 & & & & & & & & & & & & 20 \\
\hline Tornacl & & & & & & & 1 & & & & & & 1 \\
\hline Tütüncü & 4 & & & & & & & & & & & & 4 \\
\hline Vekil & & & & & 1 & & & & & & & & 1 \\
\hline Toplam & 283 & 39 & 43 & 204 & 326 & 72 & 309 & 255 & 38 & 78 & 95 & 67 & 1.809 \\
\hline
\end{tabular}

Bütün bu meslek erbâbı arasında cizye evraklarına göre nasıl bir dağılımın var olduğuna dikkat çekmek gerekirse; a'lâ evrakın sadece merkezde bulunan meslek erbâbına ait olduğunu söylemek mümkündür. Bu meslek erbâbından Antakya Rum taifesi içerisinde a'lâ evraka sahip neccar (10 kişi), attar (2 kişi) ve kuyumcu (1 kişi)'den oluşan toplam 13 vergi mükellefi bulunmaktadır. Diğer meslek erbâbı arasında en yoğun sınıfın evsât ve ednâ sınıflar olduğu söylenebilir.

Günlük mahallesinde Rumlar (8 kişi) ve Yahudiler (8 kişi) birlikte yaşamaktadır. Bu vergi mükelleflerinden Rumlar 5 evsât ve 3 ednâ; Yahudilerin ise tamamı ednâ kaydedilmiştir. 30 kişiden oluşan Kantara mahallesinde ise 19 Rum ve 11 Yahudi vardı. Rumların 9'u evsât, 10'u ednâ'dır. Yahudilerin ise 4'ü evsât, 7'si ednâ'dır. Kastal mahallesinde ise sadece Rum olarak 15 evsât vergi mükellefi ikamet etmektedir. Kocaabdi mahallesindeki 4 Yahudiden üçü evsât, biri ednâ evraka

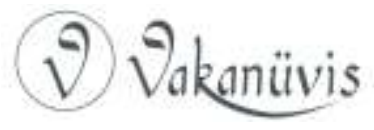


sahiptir. Mahsen mahallesindeki Rumlar ile Ermeniler bir arada yaşamaktadır. Rumlar arasında altı a'lâ, 20 evsât ve 18 ednâ vergi mükellefi bulunurken, Ermeni taifesi arasında ise 1 evsât ve 2 ednâ vergi mükellefi vardı. 3 kişiden oluşan Mukbil mahallesinde 1 a'lâ ve iki ednâ Rum; yine sadece Rumların yaşamakta olduğu Sarı mahallesinde ise 17 ednâ, Sarı Mahmud mahallesinde ise 5 a'lâ, 31 evsât ve 25 ednâ vergi mükellefi bulunmaktaydı(bkz. Tablo 11).

Sofular mahallesinde ve Tabi-i Sofular mahallesinde sadece Ermeniler vardı. Birincisinde 4 adet evsât ve 2 ednâ mükellefe karşılık ikincisinde 1 evsât ve 1 ednâ mükellef bulunuyordu. Şenbek mahallesinde ise sadece Rumlar olup, bunlardan biri a'lâ, dördü evsât ve üçü ednâ cizye evrakına sahipti(bkz. Tablo 11).

Tablo 11. 1846 Tarihli Tahrire Göre Antakya Mahallelerindeki Vergi Mükellefleri

\begin{tabular}{|c|c|c|c|c|c|c|c|c|c|c|}
\hline \multirow[t]{2}{*}{ Mahalleler } & \multicolumn{3}{|c|}{$\begin{array}{c}\text { Antakya Rum } \\
\text { Taifesi }\end{array}$} & \multicolumn{3}{|c|}{$\begin{array}{c}\text { Antakya Yahudi } \\
\text { Taifesi }\end{array}$} & \multicolumn{3}{|c|}{$\begin{array}{c}\text { Antakya Ermeni } \\
\text { Taifesi }\end{array}$} & \multirow{2}{*}{ 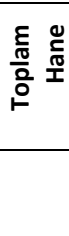 } \\
\hline & $\frac{<\pi}{2}$ & 党 & $\begin{array}{l}<\pi \\
\frac{5}{0} \\
\text { W }\end{array}$ & $\frac{\leq \pi}{i}$ & 莺 & \begin{tabular}{|l}
$<\pi$ \\
$\frac{5}{0}$ \\
年
\end{tabular} & $\frac{\leq \pi}{i}$ & 党 & $\begin{array}{l}<\pi \\
\frac{5}{0} \\
\text { W }\end{array}$ & \\
\hline Cünte & 1 & 34 & 42 & & & & & & & 77 \\
\hline Dört Ayak & & & & & & & & 2 & 17 & 19 \\
\hline Dut & & & & & 2 & 5 & & 7 & & 14 \\
\hline Dut Dibi & & & & 1 & 3 & & & 1 & & 5 \\
\hline Günlük & & 5 & 3 & & & & & & 8 & 16 \\
\hline Kantara & & 9 & 10 & & 4 & 7 & & & & 30 \\
\hline Kastal & & 15 & & & & & & & & 15 \\
\hline Koca Abdi & & & & & 3 & 1 & & & & 4 \\
\hline Mahsen & 6 & 20 & 18 & & 1 & 2 & & & & 47 \\
\hline Mukbil & 1 & & 2 & & & & & & & 3 \\
\hline Sarı & & & 17 & & & & & & & 17 \\
\hline $\begin{array}{l}\text { Sarı } \\
\text { Mahmud }\end{array}$ & 5 & 31 & 25 & & & & & & & 61 \\
\hline Sofilar & & & & & 4 & 2 & & & & 6 \\
\hline Tabi-i Sofilar & & & & & & & & 1 & 1 & 2 \\
\hline Şenbek & 1 & 4 & 3 & & & & & & & 8 \\
\hline Tabii & & & & & 3 & 4 & & & & 7 \\
\hline Urc & & & & & 1 & & & & & 1 \\
\hline Toplam & 14 & 118 & 120 & 1 & 21 & 21 & & 11 & 26 & 332 \\
\hline
\end{tabular}


1846 tahririne göre Antakya'ya 18 ayrı yerden "mürûr ü ubûr" eden yani gelip gidenlerin olduğu tespit edilebilmektedir. Bu yerlerin bir kısmı Antakya'ya bağlıyken, kalanlar büyük oranda Antakya dışındandı. Gelip gidenlerden 16'sı evsât evrak sahibi iken, 50 kişi de ednâ evraklıydı. Söz konusu kişiler arasından Halep'ten gelenler dokuz kişidir. Bunların altısı evsât, üçü ednâ evraka sahiptir. Elbistan'dan gelen 1 kişi ise evsât evraklıydı. Kürtli'den gelenler ise sadece 1 kişidir ve bunun evrakı ise evsâttır. Arapgir'den gelen 4 kişiden biri evsât, üçü ednâ evraka sahiptir. Zahle'den ise 2 kişi gelmiştir. Biri evsât diğeri ednâ evraklıdır. İdlib'ten ise 3 ednâ, Kilis'ten 1 ednâ, Tarsus'tan 2 ednâ, Tire'den 1 ednâ, Urfa'dan 4 ednâ, Trablus'tan 15 ednâ, Zeytun'dan 4 ednâ, Beylan'dan 3 ednâ ve Mısır'dan 1 ednâ evrak sahibinin gelmiş olduğu anlaşılmaktadır (bkz. Tablo 12).

Bunların dışında Yoğunoluk karyesinden bir evsât, Sarı Mahmud mahallesinden bir ednâ, Zeytuniye karyesinden ise iki ednâ evrak sahibi Antakya'ya gelmiştir (bkz. Tablo 12). 1846 tarihli tahrire göre Antakya'ya gelip gidenlerin toplamı 66 kişi olduğu anlaşılmaktadır.

Tablo 12. 1846 Tarihli Tahrire Göre Antakya'ya Gelip Giden Vergi Mükellefleri

\begin{tabular}{|l|r|r|}
\hline Antakya'ya Gelenlerin Tabi Oldukları Yerler & Gelip Giden & Toplam \\
\hline Halebli & 9 & $\mathbf{9}$ \\
\hline Yoğunoluk & 1 & $\mathbf{1}$ \\
\hline Kürtli & 11 & $\mathbf{1 1}$ \\
\hline Elbistan & 1 & $\mathbf{1}$ \\
\hline Arabgir & 4 & $\mathbf{4}$ \\
\hline Sarı Mahmud & 1 & $\mathbf{1}$ \\
\hline Zahle & 2 & $\mathbf{2}$ \\
\hline İlib & 3 & $\mathbf{3}$ \\
\hline Kilisli & 1 & $\mathbf{1}$ \\
\hline Tarsus & 2 & $\mathbf{2}$ \\
\hline Tireli & 1 & $\mathbf{1}$ \\
\hline Urfalı & 4 & $\mathbf{4}$ \\
\hline Trablus & 15 & $\mathbf{1 5}$ \\
\hline Zeytun & 4 & $\mathbf{4}$ \\
\hline Beylan & 3 & $\mathbf{3}$ \\
\hline Zeytuniye & 2 & $\mathbf{2}$ \\
\hline Sipah & 1 & $\mathbf{1}$ \\
\hline Mısır & 1 & $\mathbf{1}$ \\
\hline Toplam & 66 & $\mathbf{6 6}$ \\
\hline
\end{tabular}

\section{(2) Vabaniuivis}


1846 tarihli tahrir defterine göre Antakya ve tabi nahiyelerde bulunan vergi mükellefleri 1683 kişi iken toplam meslek erbâbı 1809 kişi olarak tespit edilebilmektedir. Buna göre vergi mükelleflerinin her biri bir hane sayılması halinde söz konusu tarihte Antakya ve nahiyelerinde 8.415 kişi, meslek erbabının her biri bir hane olarak farz edildiğinde Antakya ve nahiyelerinde toplam 9.045 kişi bulunduğu söylenebilir. Bu durumda 1842 tahririnde vergi mükellefleri hane olarak kabul edildiğinden iki tahrir arasında 220 kişi 1846 tahririnde düşüş olduğu görülürken, 1846 dönemindeki meslek erbabının her biri bir hane kabul edildiğinde 1846 dönemi lehine 410 kişilik nüfus artışı olduğu söylenebilir.

Bütün bu tahrir dönemlerinde vergi mükellefleri Antakya ve nahiyelerindeki nüfus için belirleyici bir faktör olmadığı açıkça görülmektedir. Bunun en önemli sebebi tahrirlerdeki eksiklikler ve hane miktarlarının tamamında verilmemiş olmasıdır. Bu sebeple nüfus artışları açısından daha doğru bir fikir edinilebilmesi için icmallerde verilen ve toplam cizye vergisini gösteren rakamlardan hareket etmek daha doğru olacaktır. Bu itibarla 1842 tarihinde Halep hazinesine giden vergi miktarı katibe ödenen 500 kuruş dahil olmak üzere 45.000 kuruş olduğu dikkate alındığında, aynı usul ile Halep hazinesine giden vergi miktarı 1843 'te 45.510 kuruş, 1844 'te 45.330 ve 1846 'da 45.930 kuruştur. Bütün bu vergileri dikkate aldığımızdı 45.000 üzerinden tahrir tarihlerine göre nüfustaki artışlar ve düşüşler daha kolay tespit edilebilir. Buna göre 1842 'de nüfus 45.000 kuruş üzerinden stabil (\%100) kabul edilirse, Antakya ve nahiyelerindeki gayrimüslim nüfus artışı 1843 'te $1,13,1844^{\prime}$ te 0,73 ve 1846 'da ise 2,06 oranında olmuştur denilebilir. Bu durumda 1846 'da gelir düşmemiş aksine $\% 2$ oranında artmış olduğuna göre hane karşılı̆̆ı olarak meslek erbabı miktarının alınmasının daha doğru olacağı sonucuna varılabilir.

\section{Sonuç}

Cizye tahrirleri gayrimüslimlerin ödemekle yükümlü oldukları bir çeşit kafa vergisi olmanın dışında, nüfus, nüfusun çeşitliliği, nüfus içerisinde yer alan kişi ve kurumların nitelik ve nicelikleri, kişilere ait eşkâl, yaş ve cinsiyetin yanı sıra sahip oldukları meslekler ve bu mesleklere ait gelirler gibi önemli verileri de içerir.

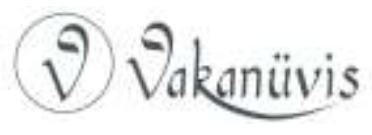


Osmanlı Devleti de bu tahrirleri yaparken şüphesiz bütün bu verilerin elde edilmesine özen göstermiştir. Soyadı kanunun olmadı̆̆ı bir zamanda insanları birbirinden ayırt etmek için, bir taraftan mükellefiyet esaslarını oluşturan bu tahrirleri yaparak kişilerin ayrıştırmasını sağlamakta, diğer taraftan nüfusun diğer milletlerle olan kıyaslamalarını yapabilmekteydi.

Osmanlıların fiskal bir anlayışla yani karlılığı düşürmemek amacıyla cizye tahrirlerini uzun zaman önce genele yayarak toplanmaktaydı. Bu uygulamaya göre vergiler doğrudan bir gruptan veya köyden, beldeden ya da topluluktan alınmaya başlanmıştı. Ferdi teşebbüsün öne çıkmaya başladığı XIX. Yüzyılda bu anlayış tamamen terk edilerek bütün bir milletin fert fert sayılmasına ve vergilerin kişi başına diğer bir deyişle kişinin yıllık belirli bir kazancı üzerinden alınmasına dair yeni bir sisteme geçilmiştir.

Bu yeni anlayış, cizye tahrirlerinin nüfus tahrirleri gibi doğrudan ferde yönelmesine ve en az nüfus tahrirleri kadar mükemmel ve düzenli tutulmuş defterlerin ortaya çıkmasına sebep olmuştur. Osmanlı Devleti'nin son dönemde kaybedilen topraklar ve halklar sebebiyle hazinenin müzayakaya uğraması, cizye gelirini önemsemeye başlanmasına ve hazinenin başlıca kaynaklarından biri haline gelmesine sebep olmuştur. Bu da cizye tahrirlerinin daha ciddi yapılmasına ve kaynakların verimli hale getirilmesine sebep olmuştur. Gayrimüslimler için hem kurumsal hem de dinsel bir veri niteliğini taşıyan bu tahrirler, cizyenin iki koldan yani hem devlet eliyle hem de kilise eliyle birbirini tekzip etmeyecek şekilde yapılmasını sağlamış, bu da verilerin sağlamasının yapılabilmesi için iki ayrı kaynağın oluşmasını temin etmiştir.

Osmanlı Devleti, yukarıda da bahsedildiği gibi meseleye nüfusu artırmak veya azaltmak açısından değil, bir gelir kapısı haline gelen cizye mükellefi sayısını düşürmemek adına bu tahrirleri yapmaya devam etmekteydi. Ancak Antakya ve çevresinde meydana gelen nüfus hareketleri bu atikleri işe yaramaz hale getirdiğinden, tahrirlerin her yıl tekrarlandığı görülmektedir.

Antakya ve çevresine ait olup 1691 cizye reformu ile 1839 Tanzimat dönemi arasında sadece 1694 cizye tahriri mevcutken, Tanzimat uygulamalarına bağlı olarak 1842, 1843, 1844, 1846 tarihlerine ait

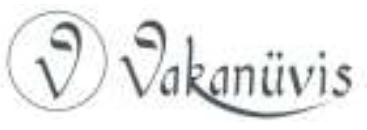


olmak üzere neredeyse her yıl yeni bir tahrir yapıldığını veya mevcut bir önceki tahririn üzerinden yeni bir tahsil yapılmış olduğu söylenebilir. Bu tahrirler Antakya merkez alınmak suretiyle Süveydiye, Cebel-i Akra ve Kuseyr olmak üzere bir merkez ve üç nahiyede yapılmıştır. 1694 cizye tahriri hariç tutulduğunda Tanzimat ve sonrası cizye tahrirleri Osmanlı Devleti açısından yapılacak reformlara harcanmak üzere geliştirilmeye çalışılan bir kaynak arayışı olarak değerlendirilebilir. Bu söylemi tahrirlerin her yıl ve ardışık olarak yapılmasıyla alakalandırabiliriz. Antakya, Süveydiye, Cebel-i Akra ve Kuseyr'den oluşan dört yerleşim biriminde gerçekleştirilen cizye tahrirlerinin 1842-1846 yılları arasında fazla bir farklılık göstermiyor olmasına rağmen, devletin tahrirleri bu şekilde ardışık tarihlerde yapıyor olması cizye vergisinin önemine işaret etmektedir.

Genel olarak vergi ve nüfus tahrirlerinin Tanzimat öncesinde ve sonrasında önemli değişkenlikler arz ediyor olması modern sayım düzenine geçilmiş olmasıyla ve hazinenin gelir kayıplarına göstermiş olduğu tepkiyle izah edilebilir. Gelir kayıplarının maliyede meydana getirdiği büyük dalgalanmaları en aza indirmek isteyen devlet 1694 tarihindekinden çok farklı bir yol izleyerek, neredeyse nüfus tahrirlerine benzer bir usul takip ederek cizye tahrirlerinde kişiler ve eşkâlleri dışında kişinin adı, mesleği, şöhreti, yaşı, göz rengi ve sıra numarası gibi bilgilere de yer vermiştir. Tablo 13'te de görüleceği üzere Antakya ve çevresinde yapılan cizye vergilerinde 1694 sonrasında hızlı bir yükselme meydana gelmiştir. Bu bölgeye yönelik gayrimüslim nüfus akını, bu artışın en önemli sebeplerinden biridir. 1842 sonrasında durağan bir hal aldığı anlaşılan bu nüfusu, 1694'e göre üç kat artmıştır. Bu da bölgenin Tanzimat ve sonrasında iyi yönetildiğine veya bölgeye bilinçli bir nüfus akışının olduğuna işaret etmektedir. Bununla beraber 1842-1846 cizye tahrirleri nüfus kadar gelir oranlarında da fazla bir değişme uğramamıştır. Buna mukabil hazine için taşıdığı öneme rağmen Osmanlı Devleti cizye gelirlerini reayayı rencide eden bir soygun vasıtası da yapmamıştır.

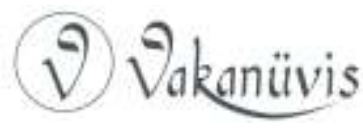


Tablo 13. 1694-1846 Yılları Arasında Cizye Tahrir Sonuçları

\begin{tabular}{|l|l|l|l|}
\hline Tarih & Kişi & Meslek Çeşidi & Toplam Kuruş \\
\hline 1694 & 561 & & \\
\hline 1842 & 1.727 & & 45.000 \\
\hline 1843 & 1.751 & 64 & 45.510 \\
\hline 1844 & 1.781 & 72 & 45.330 \\
\hline 1846 & 1.809 & 67 & 45.430 \\
\hline
\end{tabular}

Bu husus Tablo 13'te de açıkça görülmektedir. 1842-1846 yılları arasında sayısal veriler incelendiğinde gayrimüslim nüfusu yıl itibariyle 30 kişi civarında bir artış göstermektedir. Buna rağmen cizye vergi oranının çok az bir değişkenlik gösterdiği açıkça görülmektedir. Yani sabit bir miktar üzerinden tahsil edilen bir meblağın mevcudiyeti dikkati çekmektedir.

1842 yılı cizye tahriri sonucunda Antakya ve çevresinde 1.727 kişinin cizye vergi mükellefi olduğu tespit edilmiştir. Tahrirlerin sonuçları açısından bir değerlendirme yapıldığında 1842 ile 1843 yılları arasında 24 kişi, 1843-1844 arasında 30 kişi, 1844-1846 tahrirleri arasında ise 28 kişiden kaynaklı bir meblağ artışı olduğu görülmektedir.

Yine Tablo 13'te mesleklere ait veriler değerlendirildiğinde, 18421846 yılları arasında mükelleflerin durumunda çok fazla bir değişim yaşanmadığı görülmektedir. En fazla mesleğin bulunduğu 1843 ile 1844 arasında 8 adet, 1844 ile 1846 arasında ise 5 adet meslek farkı tespit edilebilmektedir.

Sonuç olarak denilebilir ki, yukarıdaki beş cizye tahririnde 1694 tahriri hariç diğer 1842, 1843, 1844 ve 1846 tahrirleri aralarında ne nüfus açısından ne de gelirdeki fazlalıklar açısından önemli bir değişkenlik yoktur. Bunun sebebi, Osmanlı Devleti'nin bütün gelir kayıplarına rağmen devlet içerisinde terör estirerek yeni gelir kapıları açmadığı gibi, var olan gelir kapılarını da geliştirmek adına zamlarla bir soygun ve zülüm aracı haline getirmemiş olmasıdır.

Buna karşılık Avrupalı devletler işgal ettikleri bölgelerde Osmanlı Devleti'nin uyguladığı vergi düzeninin tam tersine kişi, sanat ve araziyi

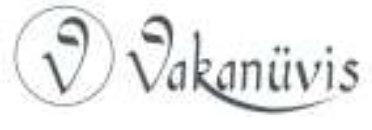


adeta sömürürcesine vergiler yüklemek suretiyle toplumu ezmeyi tercih etmişlerdi.

Tahrirlerin tamamı söz konusu edildiğinde ortaya çıkan önemli sonuçlardan biri, 1694 sayımı hariç tutulacak olursa, 1842-1846 tarihli sayımların tamamında Antakya ve nahiyelerinde 65-80 civarında esnaf ve sanatkârın varlığıdır. Esnaf ve sanatkârın bu kadar çeşitli olması şehrin genelinde canlı bir ticari hayatın varlığıyla izah edilebilir. Diğer bir sonuç ise bu esnafın genel olarak deri, kumaş ve kösele sanatında uzmanlaşmış bir kadroya sahip olmasıdır. Bunu şehirdeki esnafın özellikle bu alanda yoğunlaşmış olmasından anlaşılmaktadır.

Esnafın uzmanlaştığı bu alanların varlığına rağmen şehirde fail denilen ve her işi yapan kişilerin çokluğu dikkat çekmektedir. 1843 tarihli tahrirde nüfusun $1 / 3^{\prime}$ ini, $1844^{\prime}$ te nüfusun $2 / 3^{\prime}$ sini ve 1846 'da ise nüfusun $1 / 2$ 'sinden fazlasını teşkil eden failler ise bu canlı ticari hayata mukabil, nüfusun büyük bir kısmının belirli bir mesleğe sahip olmadığının bir göstergesi sayılabilir. Bu durum Antakya'nın doğudan gelen ticaret yolları üzerinde bulunan bir şehir olmasına rağmen nüfusun büyük kısmının kırsal kesimde bulunmasından kaynaklı işsizlik oranının yüksekliğiyle açıklanabilir.

Sonuç olarak denilebilir ki, Antakya ve nahiyeleri 1694 cizye tahriri hariç tutulduğunda 1842-1846 yılları arasında cizye ve nüfus açısından giderek artan bir oranda devlet hazinesini desteklemiş olmakla beraber, nüfusun gözle görülür bir artış kaydetmemiş olduğu söylenebilir. Bu durum özellikle 1720'li yıllarda bölgede yaşanmış olan dinsel ve mezhepsel depresyonların şehir ve civar bölgelerden gayrimüslim nüfusun büyük oranda göçerek daha güvenli bölgelere gitmesiyle ilişkilendirilebilir.

\title{
Kaynakça
}

\author{
Arşiv Kaynakları (Nüfus ve Cizye Defterleri) \\ BOA, Cevdet Dâhiliye, nr. 186/9275, s. 1-31 \\ BOA, D.CMH, nr. 120/26681, s. 1-17 \\ BOA, ML. VRD. CMH, nr. 138, s. 1-31. \\ BOA, ML.VRD.CMH, nr. 215/02-3. \\ BOA, ML.VRD.CMH.d, nr. 573.
}

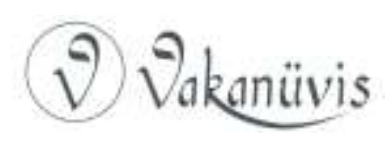




\section{Kitap ve Makaleler}

Afyoncu, Erhan, "Türkiye'de Tahrir Defterlerine Dayalı Olarak Hazırlanmış Çalışmalar Hakkında Bazı Görüşler", Türkiye Araştırmaları Literatür Dergisi, 1/1, İstanbul 2003, s. 267-286.

Ahmet Lütfi Efendi, Tarih-i Lütfi, c. III, Dersaadet 1292.

Aktepe, Münir, "Tuzcu-oğulları İsyanı", Tarih Dergisi, c. 3, Sayı: 5-6, İstanbul 1953, s. 21-52.

Akyüz, Jülide, "19. Yüzyılda Antakya-İskenderun Bölgesinde Nüfus Hareketliliği", Fırat Üniversitesi Sosyal Bilimler Dergisi, c. 18, Sayı: 2, s. 379-401.

Arıkan, Zeki, "Tapu-Tahrir Defterleri Yayınıyla Ilgili Bir Tasarı", Osmanlı Araştırmaları, c. XIII, İstanbul 1993, s. 69-74.

Aydın, Mahir, "Sultan II. Mahmud Döneminde Yapılan Nüfus Tahrirleri", Sultanll. Mahmud ve Reform Semineri, 28-30 Haziran 1989, İstanbul 1990, s. 81-106.

Barkan, Ömer Lütfi, "Tarihi Demografi Araştırmaları ve Osmanlı Tarihi", Türkiyat Mecmuası, Sayı: X, 1953, s. 1-26.

Bell, Gertrude, Review of The Civil Administration Mesopotamia, Dublin 1920.

Çakar, Enver, "16. Yüzyılda Antakya Vakıfları (1550 Tarihli Evkaf Defterine Göre)", Vakıflar Dergisi, Sayı: 43, Haziran 2015, s. 9-39.

Çimen, Adnan, "Sayım, Kayıt Düzeni Ve Teşkilatlanma Açısından Osmanlıda Nüfus Hizmetleri", Gazi Üniversitesi iktisadi ve Idari Bilimler Fakültesi Dergisi, Sayı: 14/3, Ankara 2012, s. 183-216.

Çoruh, Haydar Osmanlı'da Değişim Rüzgârları (Azınlıkların Yükselişi), Mustafa Kemal Üniversitesi Yayınları, No: 45, Hatay 2013.

Çoruh, Haydar, "Melkit Patrikliğinin Kuruluşu Ve Osmanlı Devleti, Papalık Ve Fransa Ille Iliş̧kileri (1853-1919)", Türk Kültürü Incelemeleri Dergisi, Sayı: 39, istanbul 2018, s. 83-126.

Çoruh, Haydar, Arap ve Rum Matranların iktidar Mücadelesi Sürecinde Antakya Ortodoks Kilisesi, Kriter Yayınları, İstanbul 2019.

Çoruh, Haydar, Temettüat Defterlerine Göre Erzurum Şehri (1845), Hatay 2018.

Dinç, Güven, "Tanzimat Dönemi Cizye Defterlerine Göre Antalya Gayrimüslimleri", Mediterranean Journal of Humanities, c. VII, Sayı: 2 (2017) , s. $159-181$.

Dinç, Yücel, Antakya (Hatay) Şehir Coğrafyası, (Yüksek Lisans Tezi, MKÜ, SEB), Hatay 2015.

Doğan, Cabir, Cizre ve Bohtan Emiri Bedirhan Bey (1802-1869), (Doktora Tezi, AKÜ, SBE), Afyonkarahisar 2010.

Emecen, Feridun M., "Sosyal Tarih Kaynağı Olarak Tahrir Defterleri", Tarih ve Sosyoloji Semineri, 28-29 Mayıs 1990: Bildiriler, İstanbul 1991, s. 149-155.

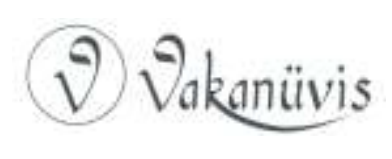


Gül, Abdülkadir, "XVI. Yüzyılda Antakya Kazası'nın Demografik Yapısı", Turkish Studies, c. 4/3, Bahar 2009, s. 1024-1066.

Gündüz, Ahmet, XVI. Yüzyılda Antakya Kazası (1550-1584), Antakya 2009.

Güneş, Mehmet, "Osmanlı Dönemi Nüfus Sayımları ve Bu Sayımları İçeren Kayıtların Tahlili", Akademik Bakış, c. 8, Sayı: 15, Kış 2014, s. 221-240.

Hüdavendigâr Livası Tahrir Defterleri (haz. Ömer Lutfi Barkan - Enver Meriçli), Ankara 1988, s. 1-144.

Inalcık, Halil "Tanzimat'ın Uygulanması ve Sosyal Tepkiler", Belleten, c. 28, Sayı: 112, Ankara 1964, s. 623-690.

İnalcık, Halil, "Cizye", DiA, c. VIII, İstanbul 1993, s. 45-48.

Kara, Adem, "XIX. Yüzyılın IIlk Yarısında Antakya'da Yerleşme ve Nüfus", OTAM (Ankara Üniversitesi Osmanlı Tarihi Araştırma ve Uygulama Merkezi) Dergisi, Sayı: 17, Ankara 2005, ss. 1-14.

Kara, Adem, 19. Yüzyılda Bir Osmanlı Şehri Antakya, IQ Yayınları, İstanbul, 2005.

Kara, Adem, XIX. Yüzyılın ilk Yarısında Antakya (1800-1850), (Doktora Tezi, A.Ü., SBE), Ankara 2004.

Karal, Enver Z., Osmanlı Imparatorluğu'nda IIlk Nüfus Sayımı (1831), Ankara 1943.

Karpat, Kemal, Osmanlı Nüfusu (1830-1914) Demografik ve Sosyal Özellikleri, Tarih Vakfı Yurt Yayınları, i̇stanbul 2003.

Kartın, Cengiz, "Türk - Ermeni İlişkilerindeki Hoşgörü Iklimi Çerçevesinde intida Hareketleri", Hoşgörü Toplumunda Ermeniler (I. Uluslararası Ermeni Sempozyumu), Kayseri, 1-4 September 2007, c. 1, ss. 521-534.

Kıvrım, İsmail, "Nüfus Ceride Defterlerine Göre 19. Yüzyılın Ortalarında Giresun'un Nüfus Yapısı", Karadeniz Incelemeleri Dergisi, Cilt 10, Sayı 10, 2011, s. 53-70.

Kocaoğlu, Burak, "Osmanlı'da Cizye Vergisi ve Ittfaiye Çalışmaları", Iğdır Üniversitesi Sosyal Bilimler Dergisi, Sayı: 10, Ekim 2016, s. 155-167.

Koçak, Zülfiye, "H. 1102 (M. 1690-1691) Tarihli Diyarbekir Eyaleti Cizye Defterinin Tanıtımı Ve Tahlili", Tarih Araştırmaları Dergisi, c. 37, Sayı: 63, 2018, s. 219-265.

Köse, Ali, "ihtidâ", DiA, c. 21, s. 554-558

Küçük, Cevdet, "Osmanlı Devleti'nde "Millet Sistemi" ", Osmanlı Ansiklopedisi, c. IV, (Edit: Güler Eren), Yeni Türkiye Yayınları, Ankara, 1999, s. 208- 216.

Küçük, Cevdet, "Osmanlılarda "Millet Sistemi" ve Tanzimat", Tanzimat'tan Cumhuriyet'e Türkiye Ansiklopedisi, c.4, İletişim Yayınları, İstanbul, 1985, s.1007- 1024. 
Öz, Mehmet, "Tahrir Defterlerinin Osmanlı Tarihi Araştırmalarında Kullanılması Hakkında Bazı Düşünceler", Vakıflar Dergisi, Sayı: 22 (1991), s. 429439.

Özcoşar, İsmail -Hüseyin Haşimi Güneş, “Osmanlı Devleti’nde Cizye Ve 19. Yüzyıla Ait Bir Cizye Defteri: Cizre Sancağı'nın Cizye Defteri (Cizye Defter Numarası:375)", Elektronik Sosyal Bilimler Dergisi, C. 5, S. 15, 2006, s. 159-179.

Sarı, Muhammed, Muttalip Şimşek, "1841 Tarihli Nüfus Defterine Göre Söke'de Rumların Nüfus Yapısı”, Uluslararası Sosyal Araştırmalar Dergisi, Cil: 9, Sayı: 44, Haziran 2016, s. 484-495.

Serbestoğlu,İbrahim “19. Yüzyılda Osmanlı Devleti'nde nüfus Algısının Değişimi Ve Nüfusu Arttırma Çabasında Müfettişlerin Rolü”, Balıkesir University The Journal of Social Sciences Institute, Volume: 17, Number: 31, June 2014, s. 255-275.

Tatar, Özcan, “Elazığ Tapu Müdürlüğü'ndeki Tapu Kayıt Defterlerinin Harput Tarihi Açısından Önemi”, Fırat Üniversitesi Harput Uygulama ve Araştırma Merkezi Geçmişten Geleceğe Harput Sempozyumu, Elazığ 23-25 Mayıs 2013, Elazığ 2013, s. 587-596.

Tutar, Adem, “Osmanlı Döneminde Antakya'nın Nüfusu ve Dini Yapısı (1860-1921)”, Fırat Üniversitesi Ilahiyat Fakültesi Dergisi, Sayı: 5, Elazığ 2000, s. 71-79. 